Int. J. Plant Sci. 178(5):378-397. 2017.

(C) 2017 by The University of Chicago. All rights reserved.

1058-5893/2017/17805-0004\$15.00 DOI: $10.1086 / 691165$

\title{
COLLETERS IN AMERICAN SPERMACOCEAE GENERA (RUBIACEAE): MORPHOANATOMICAL AND EVOLUTIONARY ASPECTS
}

\author{
Marina D. Judkevich, ${ }^{1, *}$ Roberto M. Salas, ${ }^{*}+$ and Ana M. Gonzalez*ł \\ *Instituto de Botánica del Nordeste, Consejo Nacional de Investigaciones Científicas y Técnicas, Universidad Nacional del \\ Nordeste, Sargento Cabral 2131, CC 209, 3400 Corrientes, Argentina; tFacultad de Ciencias Exactas y Naturales y Agrimensura, \\ Universidad Nacional del Nordeste, Sargento Cabral 2131, CC 209, 3400 Corrientes, Argentina; and ¥Facultad de \\ Ciencias Agrarias, Universidad Nacional del Nordeste, Sargento Cabral 2131, \\ CC 209, 3400 Corrientes, Argentina
}

Editor: Maria von Balthazar

Premise of research. The primary goal of this study is to describe the colleters on vegetative and reproductive organs in the Spermacoceae tribe and to characterize their morphoanatomy, their distribution, and some functional and evolutionary aspects.

Methodology. The anatomy, development, and vascularization of colleters from 28 species were studied using standard light and scanning electron microscopy based on fresh and fixed material. Our results are interpreted within the framework of recent molecular phylogenies.

Pivotal results. Standard-type colleters were found on stipules, calyx, and bracteoles, and they were also found on underground buds in five species of Galianthe. Six species have green colleters, and two have vascularized colleters. We discuss previously unknown functional aspects based on the Staelia glandulosa colleters and propose a new term: long-lived colleters.

Conclusions. This article describes the anatomy of colleters in the Spermacoceae tribe of the family Rubiaceae in detail. The presence of underground colleters in Galianthe grandifolia is confirmed and extended to other species of the genus. Vascularization is recorded for the first time in colleters of Mitracarpus and Staelia. This study provides data about the type, distribution, and anatomy of colleters in Spermacoceae, contributing important information for ongoing phylogenetic studies in the tribe. The proposal of a new functional type of colleter based on anatomical, morphological, and ecological aspects, named long-lived colleter, reflects the need to perform further comprehensive studies based on multidisciplinary approaches.

Keywords: green colleters, long-lived colleters, Spermacoceae, vascularized colleters.

\section{Introduction}

The Rubiaceae is one of the five most species-rich flowering plant families, with ca. 13,000 species (Goevarts et al. 2011), divided into three subfamilies (Rubioideae, Ixoroideae, and Cinchonoideae), 40 tribes, and ca. 620 genera. In Rubioideae, the tribe Spermacoceae is one of the most species-rich lineages. It has 61 genera and ca. 1235 species, which are distributed in intertropical and subtropical areas of the Americas, Africa, Oceania, and Australia (Groeninckx et al. 2009). Recent phylogenetic studies on the tribe Spermacoceae demonstrate the existence of several monophyletic clades, of which the Spermacoce clade is deeply nested among the remaining genera of the tribe (Groeninckx et al. 2009). The clade is an often-herbaceous group, with plants generally characterized

\footnotetext{
${ }^{1}$ Author for correspondence; e-mail: marina-judkevich@hotmail .com.
}

Manuscript received May 2016; revised manuscript received September 2016; electronically published April 3, 2017. by the following combination of characters: fimbriate stipules, uniovulate ovary locules, and pluriaperturate pollen grains. In the Americas, the Spermacoce clade comprises 23 genera with more than 400 species (Salas et al. 2015; R. M. Salas, unpublished data).

Colleters are structures that secrete sticky substances. Their main function is to protect the developing meristem against desiccation (Solereder 1908; Robbrecht 1988; Thomas and Dave 1989; Thomas 1991; Appezzato-da-Gloria and Estelita 2000; Klein et al. 2004; Mayer et al. 2013). They also protect the meristems of shoot apices and lateral buds against insect and pathogen attacks (Miguel et al. 2006). However, the occurrence of colleters is not limited to vegetative organs; they also occur on reproductive organs (Gonzalez and Tarragó 2009; Mayer et al. 2011; Gonzalez et al. 2012). In Rubiaceae, it has further been proposed that colleter secretion participates in nutritional aspects of the bacterial leaf nodule symbiosis (Lersten 1975).

Morphologically, colleters are multicellular trichomes consisting of a parenchymatous middle axis surrounded by a layer 
of secretory palisade-like epidermal cells. Because colleters develop from both protoderm and the underlying meristem, they are considered as emergences (Dave et al. 1988; Robbrecht 1988; Thomas 1991). This structural organization is seen in the most common type of colleter, known as the "standard type" (Lersten 1974a, 1974b). However, other types of colleters are also recognized in Rubiaceae depending on their morphology (Lersten 1974a, 1974b; Robbrecht 1988; Thomas 1991; Coelho et al. 2013).

Colleters are present in more than 60 angiosperm families, and the number is increasing with research progress (Thomas and Dave 1989; Muravnik et al. 2014). They have received special attention in Rubiaceae in recent years, because their morphology, abundance, and distribution are of taxonomic relevance (Robbrecht 1988; Thomas 1991; De Block 2003; Taylor 2003).

The aim of this study was to describe the colleters on vegetative and reproductive organs in the tribe Spermacoceae and characterize their morphoanatomy and distribution. The results are interpreted and discussed based on phylogenetic trees, so that some evolutionary questions can be answered, such as whether genera with the same pattern of colleter distribution are phylogenetically related and how many times vascularized colleters appear independently. A new insight in their functionality is discussed based on Staelia glandulosa, and a new functional type is proposed: "long-lived colleters."

\section{Material and Methods}

\section{Studied Taxa}

We studied 28 species belonging to 13 genera of the tribe Spermacoceae. Voucher specimens were deposited in the herbarium of the Instituto de Botánica del Nordeste, Corrientes, Argentina (appendix). Living material was collected in the field, and vegetative and reproductive parts were preserved in formalin-acetic acid-alcohol $(5 \mathrm{~mL}$ formalin, $5 \mathrm{~mL}$ acetic acid, and $90 \mathrm{~mL} \mathrm{50 \%} \mathrm{ethanol).} \mathrm{Samples} \mathrm{from} \mathrm{two} \mathrm{species} \mathrm{were} \mathrm{analyzed}$ from herbarium specimens; they were previously expanded in $2.5 \%$ aqueous $\mathrm{NaOH}$. Most of the species analyzed in this study belong to the Spermacoce clade, whereas other genera, such as Manettia Mutis ex L. and Oldenlandia L., belong to the former tribes Manettieae and Hedyotideae, respectively. The last two tribes were recently incorporated into Spermacoceae, mainly on the basis of molecular studies. Our sampling represents native species from Argentina, Brazil, and Mexico; only Oldenlandia corymbosa is an Asian weed that is widespread in the tropics.

\section{Light Microscopy}

Fixed and rehydrated herbarium material was analyzed and imaged under a Leica MZ6 (Leica Microsystems) dissecting microscope to determine the number and morphology of the colleters and their positions on the organs. For light microscopy observations, fixed material was dehydrated and embedded in paraffin (Johansen 1940; modified according to Gonzalez and Cristóbal 1997), then cut into 10-12- $\mu \mathrm{m}$ sections using a Microm HM350 rotary microtome (Microm International, Walldorf, Germany). Both cross and longitudinal sections were stained with safranin and Astra blue (Luque et al. 1996) and mounted in synthetic Canada balsam. Observations and digital images were acquired using a Leica DM LB2 (Leica Microsystems) light microscope equipped with a Leica digital camera. A camera lucida was used for the drawings. The presence of crystals and xylem was confirmed by observations with polarized filters. Fresh material was hand-sectioned, and the autofluorescence of plastid chlorophyll was detected using a Leica DM 1000 (Leica Microsystems) fluorescence microscope with a UV-2B filter. The node and stipules in some species were also cleared with sodium hypochlorite $(\mathrm{NaOCl})$ to examine their vasculature (Johansen 1940).

\section{Scanning Electron Microscopy}

For scanning electron microscopy, fixed material was dehydrated in an increasing acetone series and then criticalpoint dried using liquid $\mathrm{CO}_{2}$ (Denton Vacuum, DCP-1, Pleasanton, NJ) and sputter-coated with gold-palladium (Denton Vacuum, Desk II, Pleasanton, NJ). The gold-coated samples were photographed with a Jeol LV 5800 (JEOL, Tokyo, Japan) at $10 \mathrm{kV}$ in the Service of Electron Microscopy facility at the Universidad Nacional del Nordeste.

The general terminology of Rubiaceae colleters follows Robbrecht (1988). Different terminologies have been used for the projections found on the stipules and interlobular sinuses of the calyx in the taxonomic descriptions of the species analyzed, such as fimbriae (Bacigalupo and Cabral 2007), laciniae (Delprete 2010; Salas and Cabral 2010), lobes (Borhidi 2006; Bacigalupo and Cabral 2007), setae (Kirkbride 1979; Delprete 2010), teeth (Bacigalupo 1996; Delprete 2010), and intercalary appendices (Bacigalupo 1996). To unify the terminology, in this study, the term "fimbria" describes those structures that are longer than they are wide, whereas the term "teeth" describes structures of a similar length and width, both in vegetative and reproductive organs.

\section{Results}

In the analyzed species of the tribe Spermacoceae, the colleters occur on the calyx, bracteoles, and stipules, and $G a$ lianthe also has colleters on underground buds. The distribution, characteristics, and number of colleters in the analyzed species are given in table 1.

\section{Colleters on Calyx}

All species have a two- to four-lobed calyx (six-lobed calyx in Richardia) with short teeth and/or fimbriae on the interlobular sinuses (fig. 1). The fimbriae can be glabrous (fig. $1 C-1 F$, $1 I$ ) or pubescent (fig. $1 G, 1 H$ ). The colleters occur at several locations: (i) on the tips of teeth and fimbriae of the interlobular sinuses (in all species except Oldenlandia corymbosa; fig. 1A-1J); (ii) on the inner surface of the calyx (in Manettia cordifolia and Manettia paraguariensis; fig. 1I); and (iii) on 
Table 1

Distribution and Characteristics of Colleters in the Analyzed Species of Spermacoceae

\begin{tabular}{|c|c|c|c|c|c|c|c|}
\hline \multirow[b]{2}{*}{ Species, organ } & \multicolumn{4}{|c|}{ Distribution of colleters } & \multirow[b]{2}{*}{ Morphology } & \multirow[b]{2}{*}{$\begin{array}{l}\text { Axis with } \\
\text { raphides }\end{array}$} & \multirow[b]{2}{*}{$\begin{array}{l}\text { Axis with } \\
\text { chlorenchyma }\end{array}$} \\
\hline & $\begin{array}{l}\text { No. teeth } \\
\text { tipped with } \\
\text { colleter }\end{array}$ & $\begin{array}{l}\text { No. fimbriae } \\
\text { tipped with } \\
\text { colleter }\end{array}$ & $\begin{array}{c}\text { No. } \\
\text { colleters } \\
\text { on border }\end{array}$ & $\begin{array}{l}\text { No. colleters } \\
\text { on inner } \\
\text { surface }\end{array}$ & & & \\
\hline \multicolumn{8}{|c|}{ Borreria brachystemonoides: } \\
\hline Calyx & $1-3$ & $\ldots$ & $\ldots$ & $\ldots$ & Conical, rare: rounded & - & $\ldots$ \\
\hline Bracteoles & $\ldots$ & $>10$ & $\ldots$ & $\ldots$ & Conical, rare: rounded & - & $\ldots$ \\
\hline Stipules & $\ldots$ & $7-9$ & $\ldots$ & $\ldots$ & Conical, rare: rounded & - & $\ldots$ \\
\hline \multicolumn{8}{|l|}{ Borreria orientalis: } \\
\hline Calyx & $1-3$ & $\ldots$ & $\ldots$ & $\ldots$ & Conical & - & + \\
\hline Bracteoles & $\ldots$ & $7-9$ & $\ldots$ & $\ldots$ & Conical & - & + \\
\hline Stipules & $\ldots$ & $7-9$ & $\ldots$ & $\ldots$ & Conical & - & + \\
\hline \multicolumn{8}{|l|}{ Borreria palustris: } \\
\hline Calyx & $1-3$ & $\ldots$ & $\ldots$ & $\ldots$ & Conical & + & $\ldots$ \\
\hline Bracteoles & $\ldots$ & $6-7$ & $\ldots$ & $\ldots$ & Conical & + & $\ldots$ \\
\hline Stipules & $\ldots$ & $7-9$ & $\ldots$ & $\ldots$ & Conical & + & $\ldots$ \\
\hline \multicolumn{8}{|l|}{ Diodia saponariifolia: } \\
\hline Calyx & 2 & $\ldots$ & .. & $\ldots$ & $\begin{array}{l}\text { Conical, rare: rounded, } \\
\text { pad-like }\end{array}$ & + & + \\
\hline Bracteoles & $\ldots$ & $4-6$ & .. & $\ldots$ & $\begin{array}{l}\text { Conical, rare: rounded, } \\
\text { pad-like }\end{array}$ & + & + \\
\hline Stipules & $3-4$ & $1-3$ & 2 & $\ldots$ & $\begin{array}{l}\text { Conical, rare: rounded, } \\
\text { pad-like }\end{array}$ & + & + \\
\hline \multicolumn{8}{|l|}{ Ernodea littoralis: } \\
\hline Calyx & $2-3$ & $\ldots$ & $\ldots$ & $\ldots$ & Conical, rare: rounded & + & $\ldots$ \\
\hline Bracteoles & $3-5$ & 5 & $\ldots$ & $\ldots$ & Conical, rare: rounded & + & $\ldots$ \\
\hline Stipules & $2-4$ & $1-3$ & $2-3$ & $\ldots$ & Conical, rare: rounded & + & $\ldots$ \\
\hline \multicolumn{8}{|c|}{ Hexasepalum apiculatum: } \\
\hline Calyx & $2-4$ & $\ldots$ & $\ldots$ & $\ldots$ & Conical, rare: cylindrical & + & $\ldots$ \\
\hline Bracteoles & $\ldots$ & $6-8$ & $\ldots$ & $\ldots$ & Conical, rare: cylindrical & + & $\ldots$ \\
\hline Stipules & $\ldots$ & $>10$ & $\ldots$ & $\ldots$ & Conical, rare: cylindrical & + & $\ldots$ \\
\hline \multicolumn{8}{|c|}{ Galianthe centranthoides: } \\
\hline Calyx & $1-2$ & $\ldots$ & $\ldots$ & $\ldots$ & Conical & + & $\ldots$ \\
\hline Bracteoles & $\ldots$ & $2-3$ & $\ldots$ & $\ldots$ & Conical & + & $\ldots$ \\
\hline Stipules & $\ldots$ & $7-9$ & $\ldots$ & $\ldots$ & Conical & + & $\ldots$ \\
\hline Underground buds & $\ldots$ & ND & $\ldots$ & $\ldots$ & Conical & + & $\ldots$ \\
\hline \multicolumn{8}{|l|}{ Galianthe fastigiata: } \\
\hline Calyx & $1-2$ & $\ldots$ & $\ldots$ & $\ldots$ & Conical & + & $\ldots$ \\
\hline Bracteoles & $\ldots$ & 2 & $\ldots$ & $\ldots$ & Conical & + & $\ldots$ \\
\hline Stipules & $\ldots$ & $7-9$ & $\ldots$ & $\ldots$ & Conical & + & $\ldots$ \\
\hline Underground buds & $\ldots$ & ND & $\ldots$ & $\ldots$ & Conical & + & $\ldots$ \\
\hline \multicolumn{8}{|l|}{ Galianthe hispidula: } \\
\hline Calyx & $1-2$ & $\ldots$ & $\ldots$ & $\ldots$ & Conical & + & + \\
\hline Bracteoles & $\ldots$ & $2-3$ & $\ldots$ & $\ldots$ & Conical & + & + \\
\hline Stipules & $\ldots$ & $7-9$ & $\ldots$ & $\ldots$ & Conical & + & + \\
\hline Underground buds & $\ldots$ & ND & $\ldots$ & $\ldots$ & Conical & + & + \\
\hline \multicolumn{8}{|c|}{ Galianthe valerianoides: } \\
\hline Calyx & $1-2$ & $\ldots$ & $\ldots$ & $\ldots$ & Conical & + & $\ldots$ \\
\hline Bracteoles & $\ldots$ & $2-3$ & $\ldots$ & $\ldots$ & Conical & + & $\ldots$ \\
\hline Stipules & $\ldots$ & $7-9$ & $\ldots$ & $\ldots$ & Conical & + & $\ldots$ \\
\hline Underground buds & $\ldots$ & ND & $\ldots$ & $\ldots$ & Conical & + & $\ldots$ \\
\hline \multicolumn{8}{|l|}{ Manettia cordifolia: } \\
\hline Calyx & $3-6$ & $0-1$ & $3-4$ & $\ldots$ & Conical, rare: rounded & + & $\ldots$ \\
\hline Bracteoles & - & - & - & $\ldots$ & Conical, rare: rounded & + & $\ldots$ \\
\hline Stipules & $>10$ & $0-3$ & $>10$ & $4-8$ & Conical, rare: rounded & + & $\ldots$ \\
\hline \multicolumn{8}{|c|}{ Manettia paraguariensis: } \\
\hline Calyx & $5-7$ & $0-1$ & $2-6$ & $\ldots$ & Conical & + & + \\
\hline Bracteoles & - & - & - & - & Conical & + & + \\
\hline Stipules & $1-2$ & $0-2$ & $>10$ & $\ldots$ & Conical & + & + \\
\hline
\end{tabular}


Table 1 (Continued)

\begin{tabular}{|c|c|c|c|c|c|c|c|}
\hline \multirow[b]{2}{*}{ Species, organ } & \multicolumn{4}{|c|}{ Distribution of colleters } & \multirow[b]{2}{*}{ Morphology } & \multirow[b]{2}{*}{$\begin{array}{l}\text { Axis with } \\
\text { raphides }\end{array}$} & \multirow[b]{2}{*}{$\begin{array}{c}\text { Axis with } \\
\text { chlorenchyma }\end{array}$} \\
\hline & $\begin{array}{l}\text { No. teeth } \\
\text { tipped with } \\
\text { colleter }\end{array}$ & $\begin{array}{l}\text { No. fimbriae } \\
\text { tipped with } \\
\text { colleter }\end{array}$ & $\begin{array}{c}\text { No. } \\
\text { colleters } \\
\text { on border }\end{array}$ & $\begin{array}{l}\text { No. colleters } \\
\text { on inner } \\
\text { surface }\end{array}$ & & & \\
\hline \multicolumn{8}{|c|}{ Mitracarpus megapotamicus: } \\
\hline Calyx & $\ldots$ & $1-2$ & $\ldots$ & $\ldots$ & Conical, rare: cylindrical & + & $\ldots$ \\
\hline Bracteoles & $\ldots$ & $3-5$ & $\ldots$ & $\ldots$ & Conical, rare: cylindrical & + & $\ldots$ \\
\hline Stipule (IF) & $\ldots$ & 12 & $\ldots$ & $\ldots$ & Conical, rare: cylindrical & + & $\ldots$ \\
\hline Stipule (EF) & $\ldots$ & $8-9$ & $\ldots$ & $\ldots$ & Conical, rare: cylindrical & + & $\ldots$ \\
\hline \multicolumn{8}{|c|}{ Mitracarpus pusillus: } \\
\hline Calyx & $\ldots$ & $1-2$ & $\ldots$ & $\ldots$ & Conical & + & $\ldots$ \\
\hline Bracteoles & $\ldots$ & $>10$ & $\ldots$ & $\ldots$ & Conical & + & $\ldots$ \\
\hline Stipule (IF) & $\cdots$ & $6-7$ & $\cdots$ & $\cdots$ & Conical & + & $\cdots$ \\
\hline Stipule (EF) & $\ldots$ & 7 & $\ldots$ & $\ldots$ & Conical & + & $\ldots$ \\
\hline \multicolumn{8}{|c|}{ Mitracarpus polygonifolius: } \\
\hline Calyx & $\ldots$ & $1-2$ & $\ldots$ & $\ldots$ & Conical & + & $\ldots$ \\
\hline Bracteoles & $\ldots$ & $3-5$ & $\ldots$ & $\ldots$ & Conical & + & $\ldots$ \\
\hline Stipule (IF) & $\ldots$ & 15 & $\ldots$ & $\ldots$ & Conical & + & $\ldots$ \\
\hline Stipule (EF) & $\ldots$ & $7-8$ & $\ldots$ & $\ldots$ & Conical & + & $\ldots$ \\
\hline \multicolumn{8}{|c|}{ Oldenlandia corymbosa: } \\
\hline Calyx & - & - & - & - & Conical, rare: rounded & - & $\ldots$ \\
\hline Bracteoles & - & - & - & - & Conical, rare: rounded & - & $\ldots$ \\
\hline Stipules & $\ldots$ & $5-8$ & $\ldots$ & $\ldots$ & Conical, rare: rounded & - & $\ldots$ \\
\hline \multicolumn{8}{|c|}{ Oldenlandia salzmannii: } \\
\hline Calyx & $1-3$ & $\ldots$ & $\ldots$ & $\ldots$ & Conical, rare: cylindrical & + & + \\
\hline Bracteoles & $2-3$ & $\ldots$ & $1-2$ & $\ldots$ & Conical, rare: cylindrical & + & + \\
\hline Stipules & $1-2$ & $\ldots$ & $1-2$ & $\ldots$ & Conical, rare: cylindrical & + & + \\
\hline \multicolumn{8}{|c|}{ Planaltina capitata: } \\
\hline Calyx & $\ldots$ & 3 & $\ldots$ & $\ldots$ & Conical, elongated & - & $\ldots$ \\
\hline Bracteoles & $\ldots$ & $>10$ & $\ldots$ & $\ldots$ & Conical, elongated & - & $\ldots$ \\
\hline Stipules & $\ldots$ & $7-9$ & $\ldots$ & $\ldots$ & Conical, elongated & - & $\ldots$ \\
\hline \multicolumn{8}{|c|}{ Psyllocarpus asparagoides: } \\
\hline Calyx & $\ldots$ & $2-4$ & $\ldots$ & $\ldots$ & $\begin{array}{l}\text { Conical, cylindrical, } \\
\text { rounded }\end{array}$ & - & $\ldots$ \\
\hline Bracteoles & $\ldots$ & $>6$ & $\ldots$ & $\ldots$ & $\begin{array}{l}\text { Conical, cylindrical, } \\
\text { rounded }\end{array}$ & - & $\ldots$ \\
\hline Stipules & $\ldots$ & $>8$ & $\ldots$ & $\ldots$ & $\begin{array}{l}\text { Conical, cylindrical, } \\
\text { rounded }\end{array}$ & - & $\ldots$ \\
\hline \multicolumn{8}{|c|}{ Psyllocarpus laricoides: } \\
\hline Calyx & $\ldots$ & $2-4$ & $\ldots$ & $\ldots$ & Conical, rare: cylindrical & - & $\ldots$ \\
\hline Bracteoles & $1-2$ & $4-7$ & $\ldots$ & $\ldots$ & Conical, rare: cylindrical & - & $\ldots$ \\
\hline Stipules & $\ldots$ & $>8$ & $\ldots$ & $\ldots$ & Conical, rare: cylindrical & - & $\ldots$ \\
\hline \multicolumn{8}{|c|}{ Psyllocarpus phyllocephalus: } \\
\hline Calyx & $\ldots$ & $4-7$ & $\ldots$ & $\ldots$ & Conical & - & $\ldots$ \\
\hline Bracteoles & $\ldots$ & $6-7$ & $\ldots$ & $\ldots$ & Conical & - & $\ldots$ \\
\hline Stipules & $\ldots$ & $>8$ & $\ldots$ & $\ldots$ & Conical & - & $\ldots$ \\
\hline \multicolumn{8}{|c|}{ Richardia brasiliensis: } \\
\hline Calyx & $1-2$ & $1-2$ & $\ldots$ & $\ldots$ & Conical, rare: cylindrical & - & + \\
\hline Bracteoles & $\ldots$ & $5-6$ & $\ldots$ & $\ldots$ & Conical, rare: cylindrical & - & + \\
\hline Stipules & $\ldots$ & $4-6$ & $\ldots$ & $\ldots$ & Conical, rare: cylindrical & - & + \\
\hline \multicolumn{8}{|c|}{ Richardia scabra: } \\
\hline Calyx & $0-1$ & $1-2$ & $\ldots$ & $\ldots$ & Conical, rare: cylindrical & - & $\ldots$ \\
\hline Bracteoles & $\ldots$ & $>5$ & $\ldots$ & $\ldots$ & Conical, rare: cylindrical & - & $\ldots$ \\
\hline Stipules & $\ldots$ & $4-6$ & $\ldots$ & $\ldots$ & Conical, rare: cylindrical & - & $\ldots$ \\
\hline \multicolumn{8}{|c|}{ Spermacoce prostrata: } \\
\hline Calyx & $1-3$ & $\ldots$ & $\ldots$ & $\ldots$ & Conical, rare: cylindrical & + & $\ldots$ \\
\hline Bracteoles & $\ldots$ & $>4$ & $\ldots$ & $\ldots$ & Conical, rare: cylindrical & + & $\ldots$ \\
\hline Stipules & $\ldots$ & $7-9$ & $\ldots$ & $\ldots$ & Conical, rare: cylindrical & + & $\ldots$ \\
\hline Staelia domingc & & & & & & & \\
\hline Calyx & $\ldots$ & 3 & $\ldots$ & $\ldots$ & Conical & - & $\ldots$ \\
\hline Bracteoles & $\ldots$ & $>4$ & $\ldots$ & $\ldots$ & Conical & - & $\ldots$ \\
\hline Stipules & $\ldots$ & 3 & $\ldots$ & $\ldots$ & Conical & - & $\ldots$ \\
\hline
\end{tabular}


Table 1 (Continued)

\begin{tabular}{|c|c|c|c|c|c|c|c|}
\hline \multirow[b]{2}{*}{ Species, organ } & \multicolumn{4}{|c|}{ Distribution of colleters } & \multirow[b]{2}{*}{ Morphology } & \multirow[b]{2}{*}{$\begin{array}{l}\text { Axis with } \\
\text { raphides }\end{array}$} & \multirow[b]{2}{*}{$\begin{array}{c}\text { Axis with } \\
\text { chlorenchyma }\end{array}$} \\
\hline & $\begin{array}{l}\text { No. teeth } \\
\text { tipped with } \\
\text { colleter }\end{array}$ & $\begin{array}{l}\text { No. fimbriae } \\
\text { tipped with } \\
\text { colleter }\end{array}$ & $\begin{array}{c}\text { No. } \\
\text { colleters } \\
\text { on border }\end{array}$ & $\begin{array}{l}\text { No. colleters } \\
\text { on inner } \\
\text { surface }\end{array}$ & & & \\
\hline \multicolumn{8}{|c|}{ Staelia glandulosa: } \\
\hline Calyx & $\ldots$ & $1-3$ & $\ldots$ & $\ldots$ & $\begin{array}{l}\text { Cylindrical, rare: } \\
\text { conical }\end{array}$ & - & .. \\
\hline Bracteoles & $\ldots$ & $>5$ & $\ldots$ & $\ldots$ & $\begin{array}{l}\text { Cylindrical, rare: } \\
\text { conical }\end{array}$ & - & $\ldots$ \\
\hline Stipules & $\cdots$ & 3 & $\cdots$ & $\cdots$ & $\begin{array}{l}\text { Cylindrical, rare: } \\
\text { conical }\end{array}$ & - & $\cdots$ \\
\hline \multicolumn{8}{|l|}{ Staelia virgata: } \\
\hline Calyx & $\ldots$ & 3 & $\ldots$ & $\ldots$ & Conical & - & $\ldots$ \\
\hline Bracteoles & $\ldots$ & $2-3$ & $\ldots$ & $\ldots$ & Conical & - & $\ldots$ \\
\hline Stipules & $\ldots$ & 3 & $\ldots$ & $\ldots$ & Conical & - & $\ldots$ \\
\hline
\end{tabular}

Note. A minus sign indicates absence, and a plus sign indicates presence. $\mathrm{EF}=$ external fimbriae; $\mathrm{IF}=$ internal fimbriae; $\mathrm{ND}=$ no data.

the margin of the calyx lobes (e.g., Richardia brasiliensis and Richardia scabra; fig. $1 J$ ).

\section{Colleters on Bracteoles}

A bracteole is a foliar organ markedly reduced to a stipular sheath and its fimbria, in which the blade is absent (fig. $1 A$, $1 K-1 L$ ). The fimbriae may be pubescent (fig. $1 L$ ) or glabrous (fig. $1 K)$. Colleters are located on the apices of the fimbriae. Oldenlandia corymbosa and the two analyzed species of Manettia lack bracteoles.

\section{Colleters on Stipules}

In general, the Rubiaceae has opposite leaves with interpetiolar stipules. In the tribe Spermacoceae, the leaf bases are fused, forming a generally fimbriate stipular sheath (fig. $2 \mathrm{~A}$, $2 B$ ). The fimbriae are glabrous (fig. $2 E-2 G, 2 J-2 L$ ) or pubescent (fig. 2H, 2I). Staelia domingosii has ternate leaves, and Staelia glandulosa has three to four leaves per node. The fourleaf condition has not previously been documented for the tribe. The margin of the stipular sheath is mostly multifimbriate in the Spermacoce clade (fig. 2A). In Manettia, the margin of the stipule is entire (fig. 2C), with some teeth and/or fimbriae. The colleters occur on the margins of the stipules of all the species studied, without any teeth or fimbriae below (fig. 2C), and also on the teeth and/or the fimbriae (fig. $2 E-2 L$ ). The fimbriae of Mitracarpus are arranged in two rows, an inner one with small fimbriae and an outer one with large fimbriae (fig. 2J). The colleters on M. cordifolia also occur irregularly on the inner distal surface of the stipules (fig. 2M).

\section{Colleters on Underground Buds}

The Galianthe species have a rhizome (Galianthe hispidula and Galianthe valerianoides) or xylopodium (Galianthe centranthoides, Galianthe fastigiata, and Galianthe grandifolia). In both cases, the species have buds with reduced leaf blades (fig. 2N). The interpetiolar stipules have a small sheath with fimbriae tipped with small colleters (fig. 2O).

\section{Colleter Morphology and Anatomy}

In all cases, the colleters are of the standard type. The colleter shape is rather uniform. The most common shape is conical, and it is rarely cylindrical or rounded (table 1; fig. 3). The colleters present on stipules are larger than those on the calyx or bracteoles (table 2). The largest stipular colleters are present in $S$. glandulosa $(520.37 \mu \mathrm{m})$ and M. paraguariensis $(372.94 \mu \mathrm{m})$, and the smallest ones are found on Psyllocarpus stipules $(44.51 \mu \mathrm{m})$. Among the calycine colleters, the largest ones occur on M. paraguariensis and S. glandulosa, whereas the smallest are found on Psyllocarpus laricoides, Psyllocarpus asparagoides, and Borreria palustris.

The colleters consist of a central axis of parenchymatous tissue covered with a palisade epidermis (fig. 4A-4D, 4F). A thin cuticle, $2-4-\mu \mathrm{m}$ thick, covers the entire structure. The cells of the axis are rectangular in longitudinal section, and they are longitudinally arranged, without any intercellular spaces. In some species, these cells have acicular needles of calcium oxalate packed in raphides (fig. $4 A, 4 B, 4 E, 4 J, 4 K$ ). The epidermal cells are typically glandular with a dense cytoplasm, densely packed around the axis. The colleters are circular or oval in cross section (fig. 4H). The analysis of fresh material of six species showed that the central axis of colleters from stipules and calyx is composed of chlorenchyma (fig. 4I$4 L)$.

\section{Vascularization}

Only Mitracarpus polygonifolius (figs. 4D, 4E, 6E, 6F) and S. glandulosa (fig. $4 F-4 H$ ) of the 28 species analyzed have vascularized colleters. Such colleters have a single vascular bundle composed of xylem and phloem elements (figs. 4D-4H, $6 E, 6 F)$. They are present on the stipules and on the tip of the reduced lobes of the calyx of $S$. glandulosa and on the longest fimbriae of the stipules in M. polygonifolius.

As described above, M. polygonifolius has opposite leaves (fig. 5A), and $S$. glandulosa has three or four leaves per node (fig. 5B-5J). Nodal vasculature is bi-, tri-, or tetralacunar, depending on the leaf arrangement. In both of these species, 
(A)

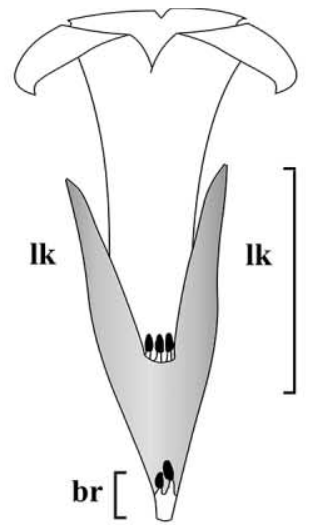

(B)

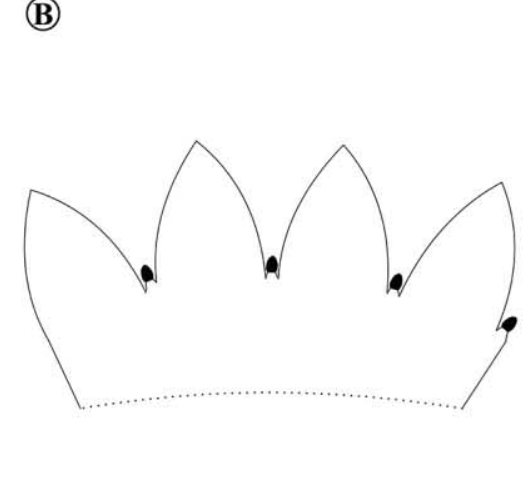

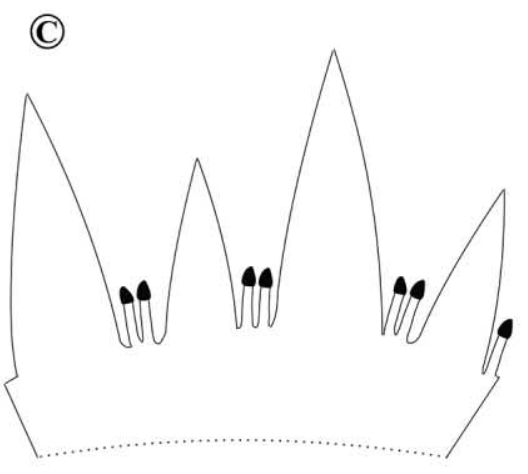

(F)

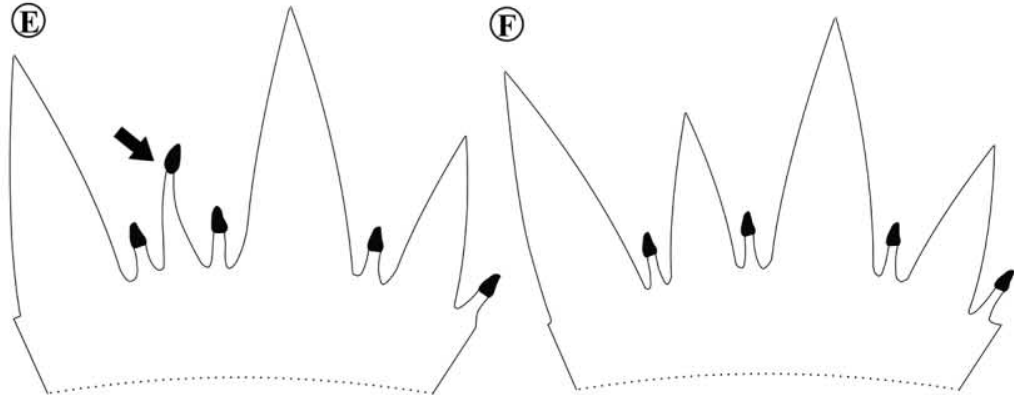

(11)

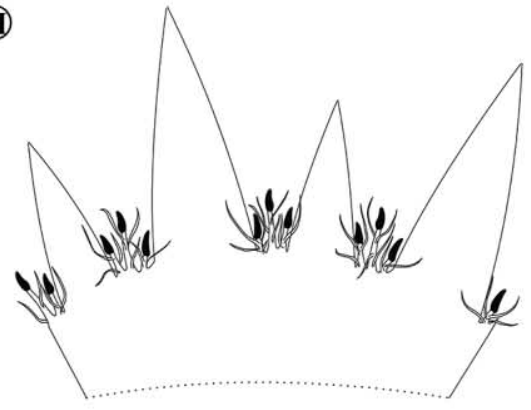

(1)

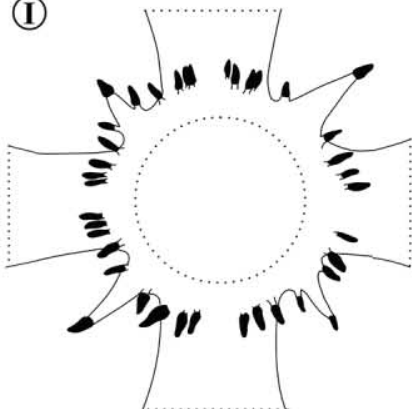

(1)

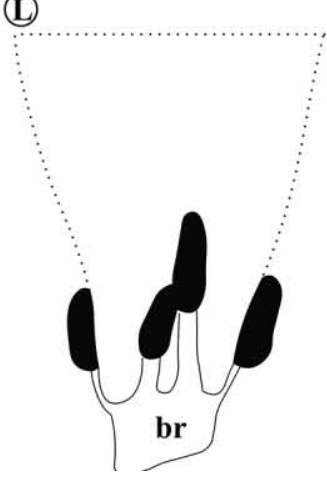

Fig. 1 Distribution of colleters in calyx and bracteoles. A, Outline of a Spermacoceae flower with colleters (in black) in the interlobular sinus of calyx (lk; in gray) and on bracteoles (br). B-H, Diagrams of unfolded calyx showing the number of sepals, fimbriae, teeth, and position of colleters (in black). B, Borreria, Ernodea littoralis, Galianthe, Hexasepalum apiculatum, Oldenlandia salzmannii, Spermacoce prostrata. C, Mitracarpus. D-F, Staelia glandulosa; note the reduction of the fourth calyx lobe to a fimbria tipped by a colleter in $E$ (arrow). G, Psyllocarpus; note the pubescent fimbriae. H, Planaltina capitata; note the pubescent fimbriae. I-J, Adaxial view of calyx tube and lobes. I, Manettia. J, Richardia. K-L, Detail of a flower with colleters on bracteoles (br). K, Psyllocarpus; note the presence of papillae and hairs on the fimbriae. $L$, Typical situation in the studied species (fimbriae glabrous). 


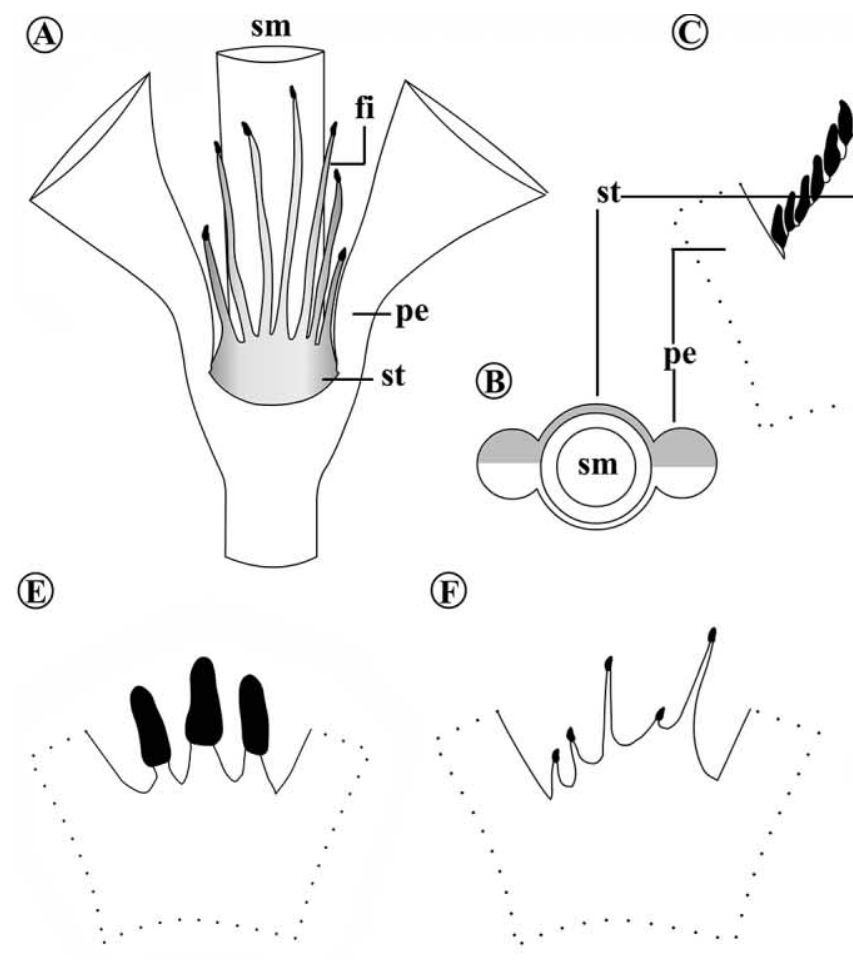

(D)

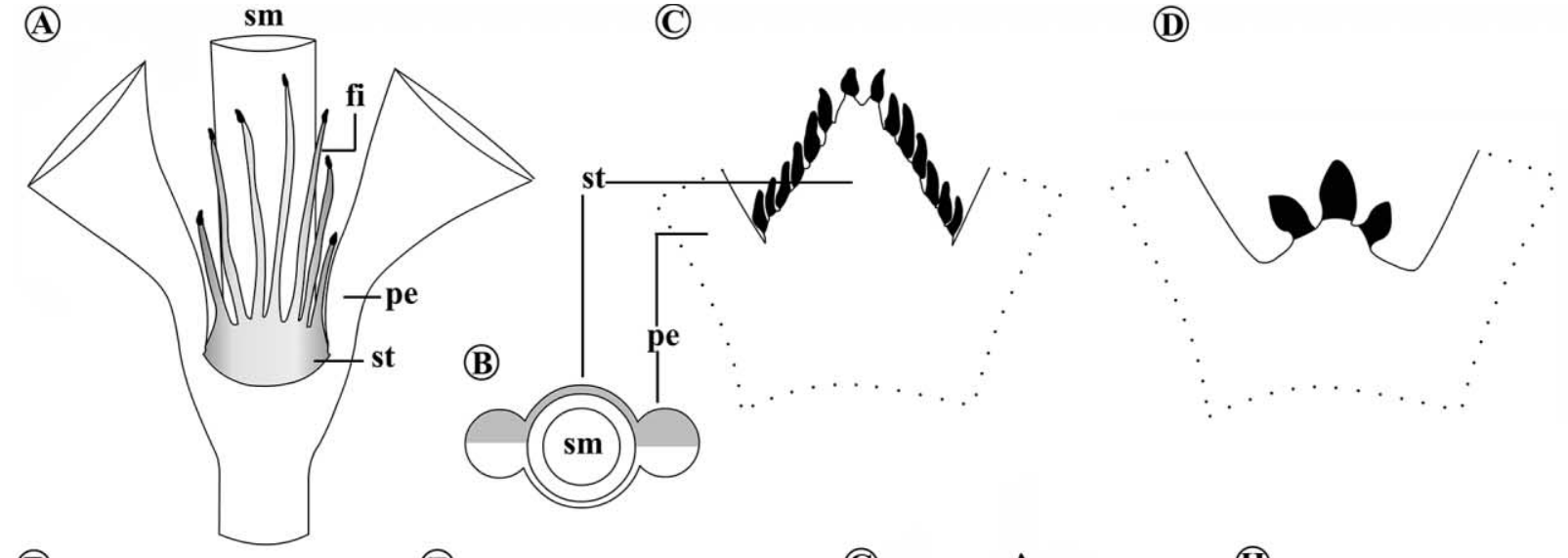

(E)

(I)
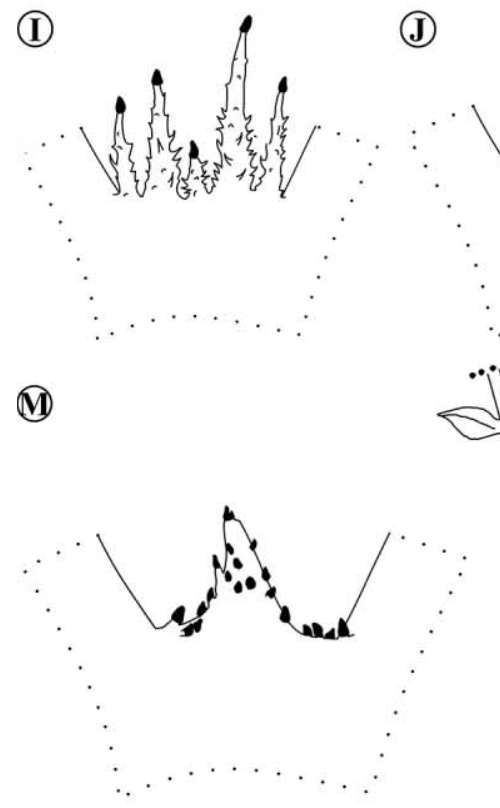

(J)

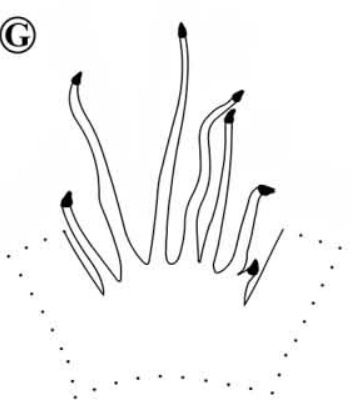

(1) (D)

(11)
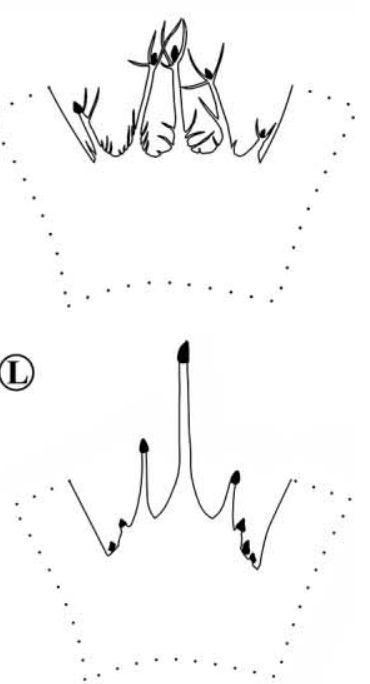

(0)

(1)
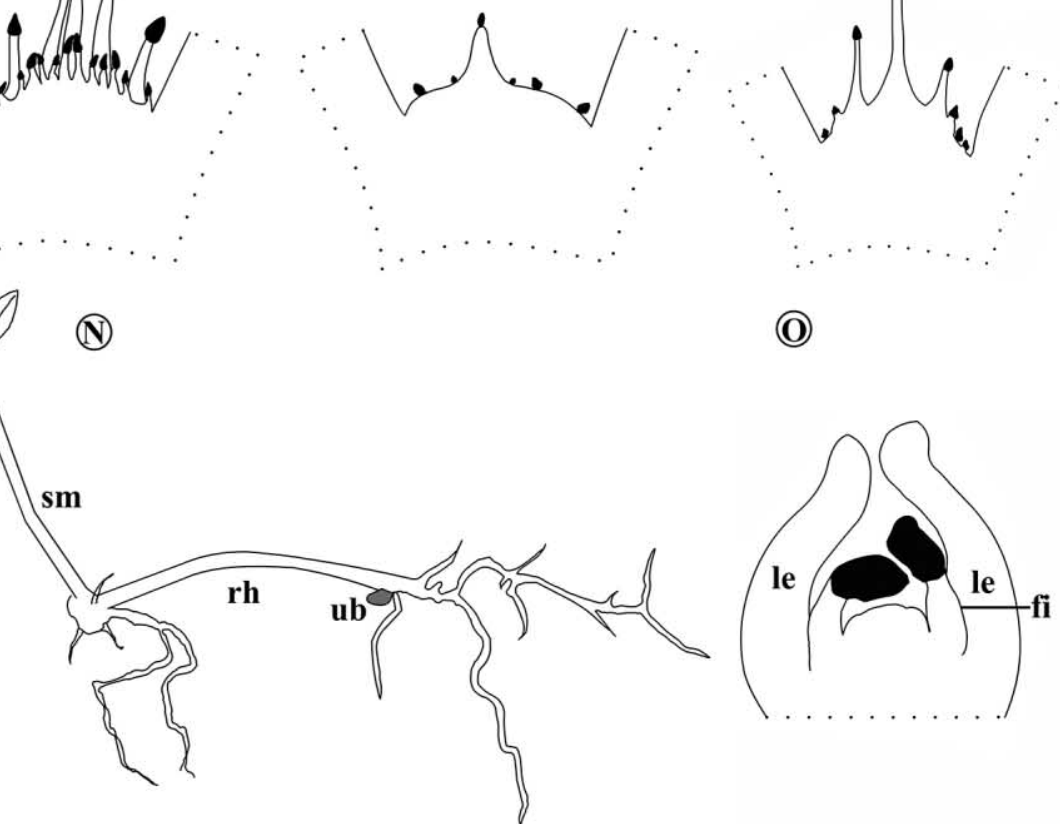

Fig. 2 Distribution of colleters on stipules and underground buds. A, Outline of a nodal region in surface view showing the position of stem $(\mathrm{sm})$, petiole (pe), interpetiolar stipules (st), and fimbria (fi) with colleters in black. B, Outline of a node in cross section. C-L, Portions of interpetiolar stipules (marked in gray in B). C, Mannettia paraguariensis. D, Oldenlandia salzmannii. E, Staelia. F, Oldenlandia corymbosa. G, Borreria, Galianthe, Planaltina capitata, Spermacoce prostrata. H, Richardia; note the pubescent fimbriae. I, Psyllocarpus; note the presence of papillae and hairs on the fimbriae. J, Mitracarpus, Hexasepalum apiculatum; note the two rows of fimbriae. K, Ernodea littoralis. L, Diodia saponarifolia. M, Manettia cordifolia; note the colleters on the inner surface. N, Outline of a stem (sm) and rhizome (rh) with underground bud (ub). O, Longitudinal section of subterranean bud in Galianthe, with modified leaves protecting the apex (le), reduced fimbriae (fi), and colleters (black). 

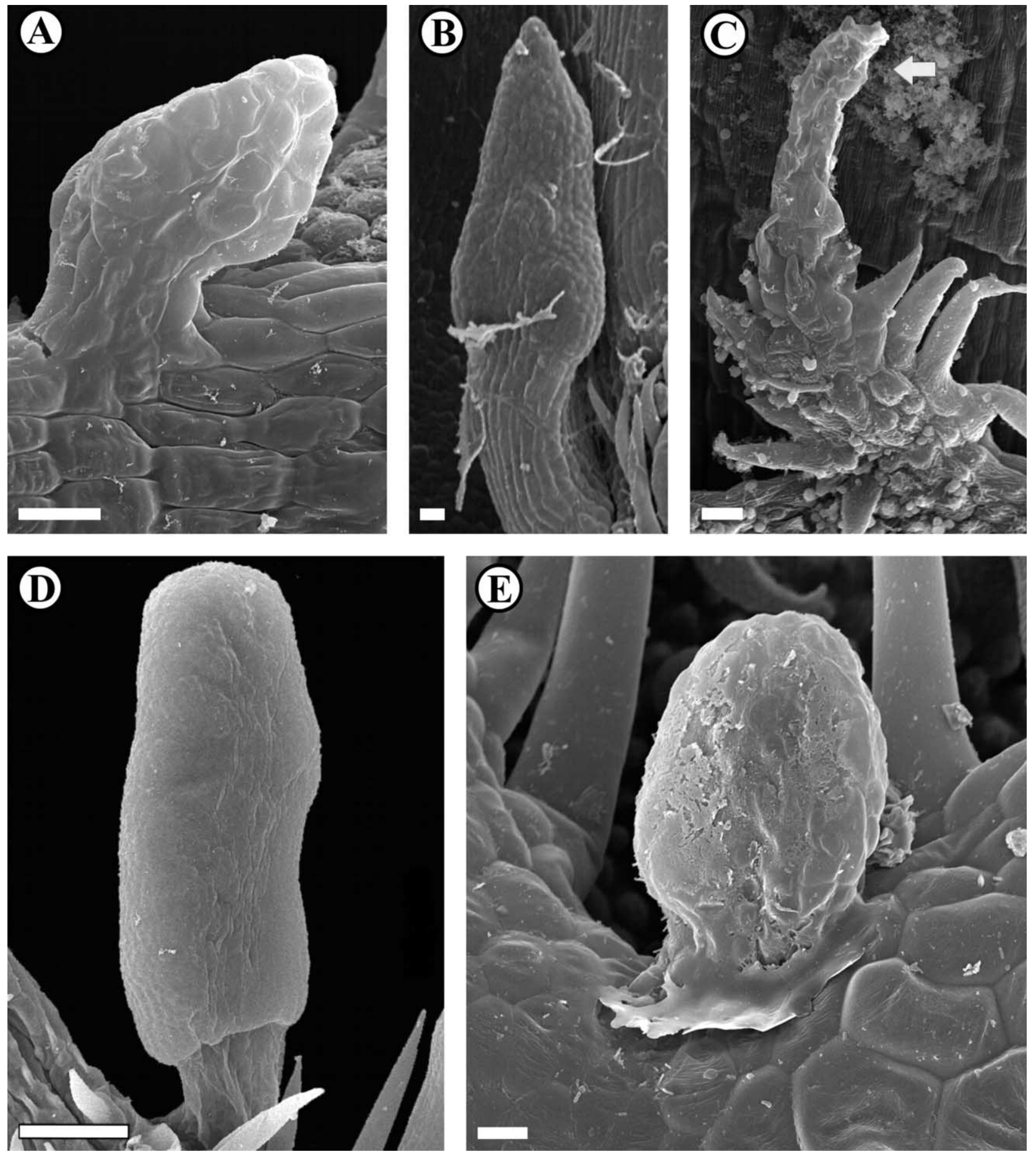

Fig. 3 Morphology of colleters (SEM). A-C, Conic colleters. A, Ernodea littoralis. B, Galianthe hispidula. C, Fimbriae of Psyllocarpus with conic colleter (arrow). D, Cylindrical colleter of Staelia glandulosa. E, Rounded colleter of Richardia brasiliensis. Scale bars: $20 \mu \mathrm{m}$.

each petiole has one median trace departing from a single gap in the central vascular cylinder (fig. 5E-5G). Two lateral traces depart from this central bundle and split immediately; the median strands complete the vascular supply of the petiole, and the external bundles extend along the stipules (fig. $5 H$ ). Several traces depart from these vascular bundles and penetrate the fimbriae, reaching the colleter (fig. $5 A, 5 B, 5 I, 5 J$ ). The vascular bundles from two adjacent leaves are connected in the interpetiolar stipule (fig. 5A-5D).

\section{Ontogeny and Secretion}

Observations of the colleter development showed a close similarity between all the studied species, and therefore only 
Table 2

Measures of Colleters in the Analyzed Species of Spermacoceae

\begin{tabular}{|c|c|c|c|c|c|c|c|}
\hline \multirow[b]{2}{*}{ Species, distribution } & \multicolumn{3}{|c|}{ Length $(\mu \mathrm{m})$} & \multicolumn{3}{|c|}{ Width $(\mu \mathrm{m})$} & \multirow[b]{2}{*}{ Length: width ratio } \\
\hline & Median & Maximum & Minimum & Median & Maximum & Minimum & \\
\hline \multicolumn{8}{|c|}{ Borreria brachystemonoides: } \\
\hline Stipule & 143.17 & 192.61 & 71.12 & 97.13 & 136.20 & 53.90 & $1.47: 1$ \\
\hline Calyx & 103.76 & 145.48 & 60.25 & 50.51 & 87.56 & 34.76 & $2.05: 1$ \\
\hline Bracteole & 133.57 & 159.18 & 79.12 & 76.68 & 135.13 & 53.83 & $1.74: 1$ \\
\hline \multicolumn{8}{|l|}{ Borreria orientalis: } \\
\hline Stipule & 393.68 & 520.08 & 267.91 & 204.48 & 238.22 & 146.23 & $1.92: 1$ \\
\hline Calyx & 177.46 & 213.85 & 133.77 & 55.89 & 74.32 & 37.78 & $3.17: 1$ \\
\hline Bracteole & 209.90 & 302.15 & 126.16 & 82.86 & 140.37 & 49.09 & $2.53: 1$ \\
\hline \multicolumn{8}{|l|}{ Borreria palustris: } \\
\hline Stipule & 314.99 & 547.43 & 209.8 & 96.95 & 107.01 & 78.95 & $3.25: 1$ \\
\hline Calyx & 59.55 & 66.68 & 52.42 & 40.97 & 46.88 & 35.06 & $1.45: 1$ \\
\hline Bracteole & 89.18 & 180.30 & 50.01 & 45.07 & 88.59 & 30.81 & $1.98: 1$ \\
\hline \multicolumn{8}{|l|}{ Diodia saponariifolia: } \\
\hline Stipule & 339.89 & 461.66 & 149.00 & 284.03 & 488.18 & 87.19 & $1.19: 1$ \\
\hline Calyx & 126.54 & 169.10 & 90.89 & 106.65 & 183.76 & 49.10 & $1.18: 1$ \\
\hline Bracteole & 204.42 & 257.60 & 136.14 & 125.46 & 191.93 & 84.88 & $1.63: 1$ \\
\hline \multicolumn{8}{|l|}{ Ernodea littoralis: } \\
\hline Stipule & 100.66 & 171.18 & 56.20 & 77.38 & 147.79 & 41.33 & $1.30: 1$ \\
\hline Calyx & 124.42 & 172.22 & 71.49 & 82.35 & 113.13 & 60.11 & $1.51: 1$ \\
\hline Bracteole & 112.34 & 137.57 & 83.59 & 84.30 & 120.32 & 42.19 & $1.33: 1$ \\
\hline \multicolumn{8}{|c|}{ Galianthe centranthoides: } \\
\hline Stipule & 110.17 & 112.54 & 107.80 & 77.44 & 83.46 & 71.42 & $1.42: 1$ \\
\hline Calyx & 104.35 & 112.84 & 95.87 & 74.08 & 77.52 & 70.64 & $1.41: 1$ \\
\hline Bracteole & ND & ND & ND & ND & ND & $\mathrm{ND}$ & ND \\
\hline Underground buds & 143.38 & 192.88 & 99.85 & ND & ND & ND & ND \\
\hline \multicolumn{8}{|l|}{ Galianthe fastigiata: } \\
\hline Stipule & 126.28 & 166.11 & 87.69 & 59.01 & 67.63 & 50.40 & $2.14: 1$ \\
\hline Calyx & 76.80 & 95.59 & 46.06 & 43.21 & 59.52 & 31.64 & $1.77: 1$ \\
\hline Bracteole & 110.71 & 116.20 & 106.82 & ND & ND & ND & ND \\
\hline Underground buds & 109.43 & 164.15 & 54.71 & ND & ND & ND & ND \\
\hline \multicolumn{8}{|l|}{ Galianthe hispidula: } \\
\hline Stipule & 238.49 & 353.70 & 140.41 & 109.51 & 203.67 & 64.08 & $2.17: 1$ \\
\hline Calyx & 115.74 & 133.43 & 90.32 & 67.52 & 101.82 & 45.96 & $1.71: 1$ \\
\hline Bracteole & 144.29 & 174.71 & 75.95 & 70.08 & 96.26 & 59.36 & $2.05: 1$ \\
\hline Underground buds & 204.56 & 298.26 & 78.77 & 118.46 & 159.70 & 70.22 & $1.73: 1$ \\
\hline \multicolumn{8}{|c|}{ Galianthe valerianoides: } \\
\hline Stipule & 112.02 & 139.19 & 84.86 & 74.58 & 83.11 & 66.05 & $1.50: 1$ \\
\hline Calyx & 161.52 & 176.93 & 152.24 & 82.29 & 90.72 & 76.41 & $1.96: 1$ \\
\hline Bracteole & ND & ND & ND & ND & ND & $\mathrm{ND}$ & ND \\
\hline Underground buds & 175.54 & 249.07 & 117.75 & ND & ND & ND & ND \\
\hline \multicolumn{8}{|c|}{ Hexasepalum apiculatum: } \\
\hline Stipule & 142.01 & 229.63 & 96.34 & 58.00 & 72.76 & 41.11 & $2.45: 1$ \\
\hline Calyx & 98.32 & 130.06 & 58.93 & 49.21 & 77.19 & 33.37 & $1.99: 1$ \\
\hline Bracteole & 120.65 & 145.84 & 89.27 & 62.46 & 80.48 & 41.20 & $1.93: 1$ \\
\hline \multicolumn{8}{|l|}{ Manettia cordifolia: } \\
\hline Stipule & 125.47 & 165.97 & 90.84 & 102.97 & 119.04 & 72.37 & $1.22: 1$ \\
\hline Calyx & 121.05 & 199.00 & 75.27 & 62.62 & 98.59 & 37.21 & $1.93: 1$ \\
\hline Bracteole & ND & ND & ND & ND & ND & ND & ND \\
\hline \multicolumn{8}{|c|}{ Manettia paraguariensis: } \\
\hline Stipule & 319.79 & 372.94 & 189.93 & 117.67 & 217.00 & 74.13 & $2.71: 1$ \\
\hline Calyx & 310.14 & 375.26 & 205.75 & 88.26 & 125.63 & 60.30 & $3.51: 1$ \\
\hline Bracteole & ND & ND & ND & ND & ND & ND & ND \\
\hline Mitracarpus megapoto & & & & & & & \\
\hline Stipule (IF) & 95.83 & 133.18 & 64.26 & 61.97 & 71.09 & 50.46 & $1.55: 1$ \\
\hline Stipule (EF) & 151.54 & 168.65 & 122.91 & 98.16 & 104.77 & 88.91 & $1.54: 1$ \\
\hline Calyx & 79.55 & 91.58 & 53.95 & 54.46 & 65.01 & 49.21 & $1.46: 1$ \\
\hline Bracteole & 77.75 & 87.95 & 56.97 & 53.08 & 76.55 & 42.52 & $1.46: 1$ \\
\hline
\end{tabular}


Table 2 (Continued)

\begin{tabular}{|c|c|c|c|c|c|c|c|}
\hline \multirow[b]{2}{*}{ Species, distribution } & \multicolumn{3}{|c|}{ Length $(\mu \mathrm{m})$} & \multicolumn{3}{|c|}{ Width $(\mu \mathrm{m})$} & \multirow[b]{2}{*}{ Length: width ratio } \\
\hline & Median & Maximum & Minimum & Median & Maximum & Minimum & \\
\hline \multicolumn{8}{|l|}{ Mitracarpus pusillus: } \\
\hline Stipule (IF) & 76.22 & 117.32 & 54.46 & 58.75 & 110.65 & 27.15 & $1.29: 1$ \\
\hline Stipule (EF) & 117.94 & 139.12 & 95.55 & 87.41 & 119.82 & 41.89 & $1.35: 1$ \\
\hline Calyx & 79.53 & 123.12 & 51.59 & 47.10 & 54.58 & 39.85 & $1.68: 1$ \\
\hline Bracteole & 114.74 & 166.14 & 85.77 & 69.31 & 82.85 & 41.94 & $1.65: 1$ \\
\hline \multicolumn{8}{|c|}{ Mitracarpus polygonifulius: } \\
\hline Stipule (IF) & 174.53 & 301.02 & 119.43 & 85.70 & 118.32 & 55.04 & $2.04: 1$ \\
\hline Stipule $(\mathrm{EF})^{\mathrm{a}}$ & 360.07 & 467.37 & 242.20 & 154.20 & 206.32 & 80.75 & $2.33: 1$ \\
\hline Calyx & 87.26 & 101.92 & 54.67 & 42.96 & 49.29 & 36.68 & $2.03: 1$ \\
\hline Bracteole & 109.88 & 123.98 & 95.04 & 49.19 & 61.19 & 36.76 & $2.23: 1$ \\
\hline \multicolumn{8}{|c|}{ Oldenlandia corymbosa: } \\
\hline Stipule & 118.92 & 143.29 & 79.72 & 86.54 & 133.62 & 58.94 & $1.37: 1$ \\
\hline \multicolumn{8}{|c|}{ Oldenlandia salzmannii: } \\
\hline Stipule & 143.80 & 175.52 & 102.49 & 118.33 & 156.33 & 92.32 & $1.21: 1$ \\
\hline Calyx & 102.82 & 169.21 & 56.28 & 78.42 & 116.55 & 40.17 & $1.31: 1$ \\
\hline Bracteole & 98.47 & 119.35 & 71.20 & 71.71 & 112.27 & 48.15 & $1.37: 1$ \\
\hline \multicolumn{8}{|l|}{ Planaltina capitata: } \\
\hline Stipule & 232.88 & 320.82 & 181.92 & 78.47 & 128.57 & 51.60 & $2.97: 1$ \\
\hline Calyx & 165.26 & 192.36 & 141.45 & 50.95 & 54.76 & 43.46 & $3.24: 1$ \\
\hline Bracteole & 157.95 & 189.22 & 135.22 & 56.32 & 66.28 & 41.36 & $2.80: 1$ \\
\hline \multicolumn{8}{|c|}{ Planaltina asparagoides: } \\
\hline Stipule & 59.55 & 81.87 & 44.51 & 41.84 & 50.83 & 32.20 & $1.42: 1$ \\
\hline Calyx & 44.28 & 50.07 & 39.15 & 39.79 & 42.43 & 35.91 & $1.11: 1$ \\
\hline Bracteole & 59.48 & 68.29 & 47.25 & 47.98 & 60.49 & 37.81 & $1.24: 1$ \\
\hline \multicolumn{8}{|l|}{ Planaltina laricoides: } \\
\hline Stipule & 62.60 & 75.49 & 50.18 & 44.88 & 58.06 & 33.71 & $1.39: 1$ \\
\hline Calyx & 52.75 & 67.84 & 46.27 & 39.72 & 45.30 & 31.52 & $1.33: 1$ \\
\hline Bracteole & 56.39 & 75.80 & 45.54 & 39.99 & 45.50 & 33.23 & $1.41: 1$ \\
\hline \multicolumn{8}{|c|}{ Planaltina phyllocephalus: } \\
\hline Stipule & 55.97 & 61.97 & 47.85 & 40.36 & 50.56 & 32.14 & $1.38: 1$ \\
\hline Calyx & ND & ND & ND & ND & ND & ND & ND \\
\hline Bracteole & 61.85 & 65.92 & 54.06 & 41.40 & 47.00 & 36.32 & $1.49: 1$ \\
\hline \multicolumn{8}{|l|}{ Richardia brasiliensis: } \\
\hline Stipule & 156.10 & 187.54 & 124.02 & 101.83 & 134.52 & 76.03 & $1.53: 1$ \\
\hline Calyx & 98.00 & 127.96 & 68.35 & 64.87 & 87.00 & 51.94 & $1.51: 1$ \\
\hline Bracteole & 116.84 & 135.40 & 103.15 & 72.90 & 115.52 & 43.05 & $1.60: 1$ \\
\hline \multicolumn{8}{|l|}{ Richardia scabra: } \\
\hline Stipule & 127.25 & 156.90 & 96.33 & 98.47 & 128.90 & 71.52 & $1.29: 1$ \\
\hline Calyx & 94.81 & 128.55 & 61.49 & 65.25 & 82.08 & 33.29 & $1.45: 1$ \\
\hline Bracteole & 90.19 & 118.92 & 39.85 & 56.78 & 72.76 & 33.46 & $1.59: 1$ \\
\hline \multicolumn{8}{|l|}{ Spermacoce prostrata: } \\
\hline Stipule & 89.05 & 103.13 & 67.79 & 41.28 & 51.38 & 25.20 & $2.15: 1$ \\
\hline Calyx & 46.15 & 48.79 & 43.52 & 28.74 & 30.85 & 26.63 & $1.61: 1$ \\
\hline Bracteole & 74.76 & 95.51 & 65.21 & 41.24 & 46.40 & 37.27 & $1.81: 1$ \\
\hline \multicolumn{8}{|l|}{ Staelia domingosii: } \\
\hline Stipule & 178.37 & 228.75 & 145.85 & 95.33 & 114.74 & 75.18 & $1.87: 1$ \\
\hline Calyx & 111.94 & 148.06 & 95.34 & 64.77 & 74.54 & 38.36 & $1.73: 1$ \\
\hline Bracteole & 149.22 & 200.62 & 115.54 & 73.70 & 88.22 & 52.43 & $2.02: 1$ \\
\hline Staelia glandulosa: & & & & & & & \\
\hline Stipule & 441.51 & 520.37 & 367.23 & 160.61 & 186.24 & 80.64 & $2.75: 1$ \\
\hline Calyx ${ }^{a}$ & 205.38 & 292.61 & 142.16 & 81.82 & 101.15 & 70.26 & $2.51: 1$ \\
\hline Bracteole & 202.47 & 260.25 & 104.02 & 130.25 & 177.99 & 69.95 & $1.55: 1$ \\
\hline Staelia virgata: & & & & & & & \\
\hline Stipule & 146.28 & 215.12 & 94.82 & 90.86 & 120.38 & 56.13 & $1.61: 1$ \\
\hline Calyx & 93.34 & 149.00 & 65.73 & 64.56 & 104.36 & 48.53 & $1.44: 1$ \\
\hline Bracteole & 109.29 & 131.00 & 80.28 & 65.93 & 79.86 & 44.56 & $1.66: 1$ \\
\hline
\end{tabular}

Notes. $\quad \mathrm{EF}=$ external fimbriae; $\mathrm{IF}=$ internal fimbriae; $\mathrm{ND}=$ no data.

a Vascularized colleter. 
the development of $S$. glandulosa will be described in detail. The colleter arises as protrusions composed of protoderm, ground meristem, and procambial cells. These meristematic cells are characterized by a dense cytoplasm and conspicuous nuclei. Both the protoderm and the ground meristem form a small dome (fig. 6A). The protoderm cells are radially elongated and undergo only anticlinal cell division; the ground meristem cells are small and isodiametric and undergo cell division in several planes (fig. 6B). Some cells of the central core of the colleters are thin and longitudinally arranged, finally forming procambial cells (fig. 6C). The colleter becomes enlarged with the successive divisions in different planes; the palisade epidermis develops from the protoderm, first becoming radially elongated and then finally palisade shaped and secretory (fig. 6D, 6E). The underlying tissue elongates and forms the central axis. The vascular system originates from the procambial cells near the colleter. The base of some colleters is constricted, and so they have a short stalk formed of shortened epidermal cells (fig. 6F).

In $S$. glandulosa, accumulated secretion was observed under the cuticle in some colleters (fig. $7 A$ ), whereas in others the secretion flowed through the broken cuticle (fig. $7 B$ ). In other species, secretion was detected on the colleters, but no rupture or presence of pores in the cuticle was observed (fig. $7 \mathrm{C}-$ $7 G)$.

Mature colleters on fresh material are senescent and ochrebrown in color (fig. $7 H$ ). In cross section, both epidermal and parenchyma cells appear deformed and collapsed (fig. 7I, 7J). Once the development of the organ is complete, the colleters collapse and generally fall off. Occasionally, they may persist as blackish, dehydrated structures; this is common in colleters found on calyces that persist on fruits.

\section{Long-Lived Colleters}

Field observations indicated that secretion was still present in old stipular colleters on $S$. glandulosa. The secretion was copious. The secretion left the stem surface shiny in the dried material. Staelia glandulosa is a scarcely branched shrub. The branches have numerous nodes with regularly distributed whorled leaves; each leaf has an axillary brachyblast. More than 60 foliar nodes were observed, of which 10-30 apical nodes bear multiflowered axillary inflorescences. Active colleters were observed on these nodes, both flowering and vegetative. As these colleters function over an extended time span, we named them long-lived colleters. In contrast, the remaining species that we analyzed in the tribe Spermacoceae have collapsed stipular colleters on the younger apical nodes that are visible to the naked eye. Normally, the collapse of the stipular colleter starts when the leaf primordia slightly surpass the stipular sheath. Therefore, completely collapsed colleters are visible on the second or third node, immediately beneath the apical node.

\section{Discussion}

\section{Distribution of Colleters on Calyx, Stipules, and Bracteoles}

Colleters are present on the teeth and fimbriae of the calyx, bracteoles, and stipules in all the species studied of the tribe
Spermacoceae, as was indicated in an earlier study (Thomas 1991). They are usually on the interlobular sinus of the calyx and on the margin of stipules. Colleters rarely occur on the margin of the calyx lobes or the calyx or inside the stipules. However, in Manettia cordifolia, the colleters cover the inner surface of the stipules, which was previously reported in the taxonomic treatment of this species (Delprete 2010). Manettia paraguariensis has no colleters on the inner surface of the stipules but shares the presence of colleters on the inner surface of the calyx lobes with M. cordifolia. Results of this study suggest that the latter feature is exclusive to the genus Manettia. Marginal colleters on the calyx lobes occur only in the genus Richardia.

The presence of colleters on the internal surface of the calyx and stipules is common in other tribes of the Rubiaceae, even in Rubioidae (e.g., on the stipules of Psychotria L., tribe Psychotrieae; Miguel et al. 2009; Vitarelli and Santos 2009; Tresmondi et al. 2015). The latter pattern is also found in Cephalanthus occidentalis L. of the tribe Naucleeae (Cinchonoideae; Rutishauser 1983) and in species of Gardenieae (Ixoroideae), such as Randia L. (Judkevich et al. 2015; Tresmondi et al. 2015). In other Gardenieae, the co-occurrence of colleters inside the stipules and calyx is very common, such as in Gardenia J. Ellis (Dave et al. 1988; Low and Wong 2007), Cordiera A. Rich. (Barreiro and Machado 2007; Tresmondi et al. 2015), Rosenbergiodendron Fagerl. (Gustafsson 1998), and Tocoyena Aubl. (Machado et al. 2007; Tresmondi et al. 2015). According to Robbrecht (1988), the distribution of colleters on the internal surface of stipules is perhaps the primitive condition.

\section{Colleters on Underground Buds}

Colleters were found on underground organs (rhizome and xylopodium) of four additional Galianthe species. This location of colleters has been previously documented only for the xylopodium of Galianthe grandifolia (Vilhalva 2008). In this study, we also extended this location to Galianthe centranthoides and Galianthe fastigiata. The buds of Galianthe valerianoides and Galianthe hispidula rhizomes were analyzed, and the presence of colleters is reported here for the first time in a rhizomatous herb.

\section{Morphology and Anatomy of Colleters}

According to the classification of colleters in Rubiaceae proposed by Lersten $(1974 a, 1974 b)$, the anatomical type of colleter in Spermacoceae belongs to the standard type. These results are consistent with earlier studies of the group (Borreria hispida K. Schum., Diodia sarmentosa Swartz., Ernodea littoralis Swartz., and Oldenlandia friesorium Bremek.; Lersten 1975). Standard colleters may be conical, cylindrical, round, or pad-like (Robbrecht 1988), with the first being the most common shape. According to Halle (1967), in species of the tribe Gardenieae, identical colleters are usually found on the calyx lobes and the stipules, and we observed the same conditions in Spermacoceae.

We observed packages of raphides in the axes of the colleters in certain species. The presence of crystals in cells of 

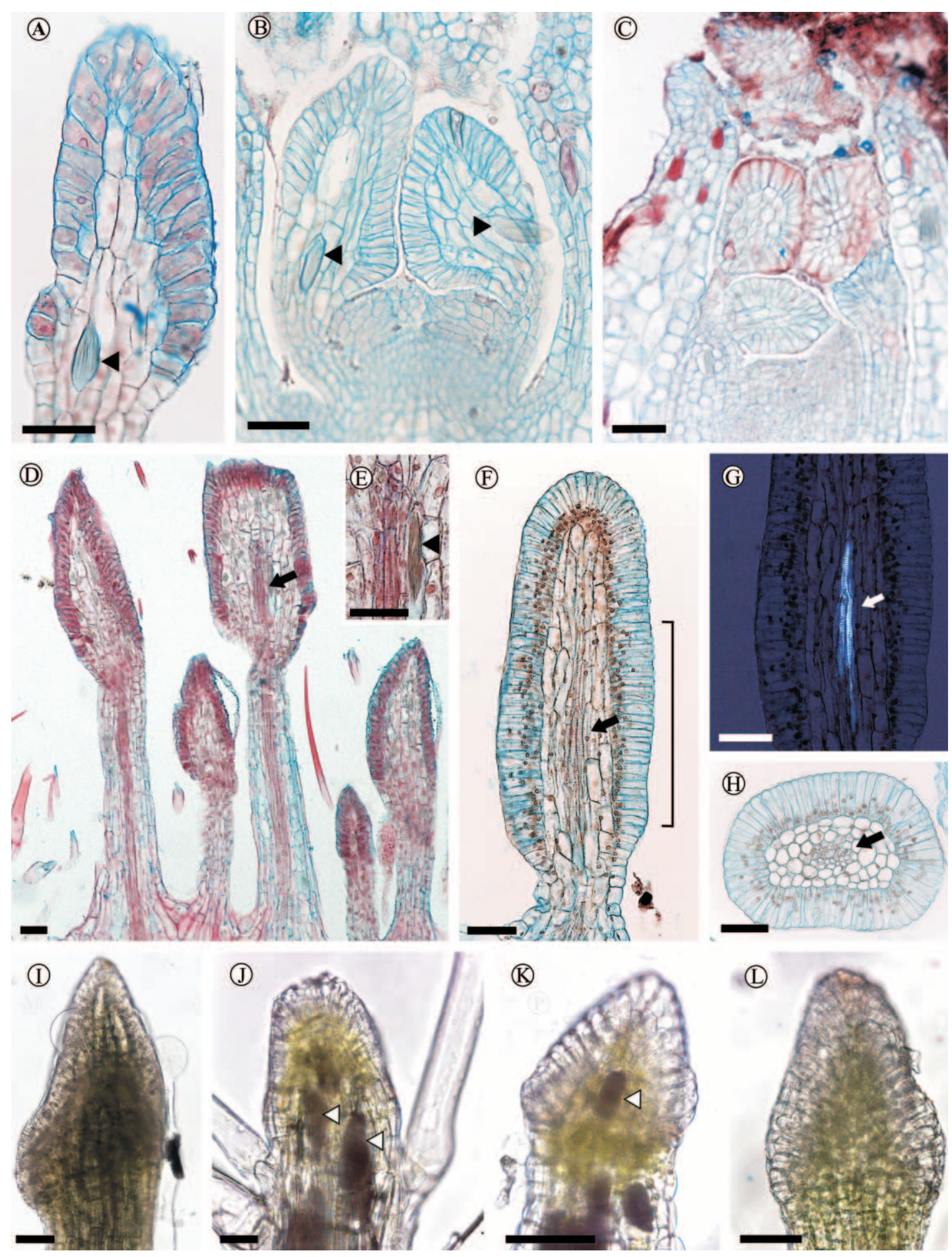

Fig. 4 Anatomy of colleters (LM). A-G, Longitudinal section of colleters. A, Manettia paraguariensis. B-C, Galianthe hispidula, colleters of the stipules $(B)$ and underground bud $(C)$. D-H, Vascularized colleters. D-E, Mitracarpus polygonifolius, note in $(E)$ the raphide next to the vascular bundle. F-H, Staelia glandulosa; note in $G$ the xylem seen with polarized light, corresponding to section marked in $F$. I-L, LM of fresh, unstained colleters showing chlorenchyma. I, Borreria palustris. J, Diodia saponariifolia. K, Galianthe hispidula. L, Richardia brasiliensis. Arrows indicate the vascular bundle, and arrowheads indicate raphides. Scale bars: $50 \mu \mathrm{m}$. 
(A)

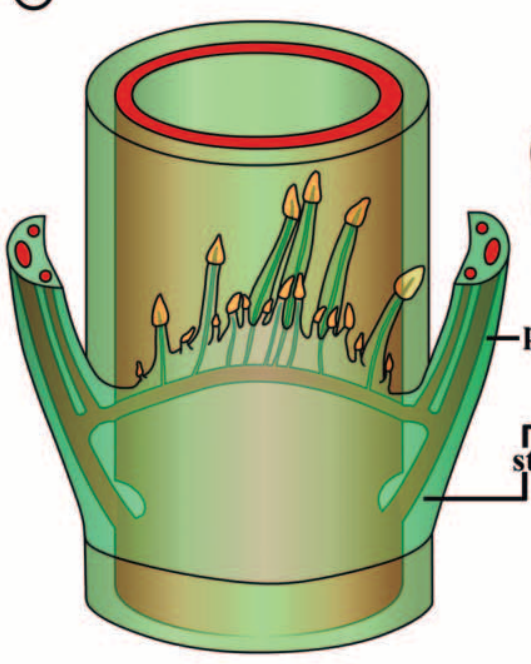

(E)

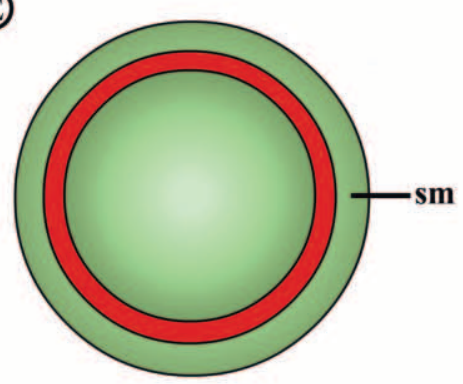

(11)

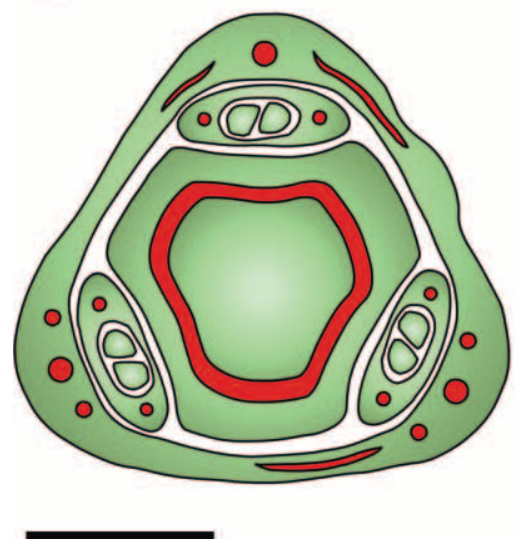

(B)

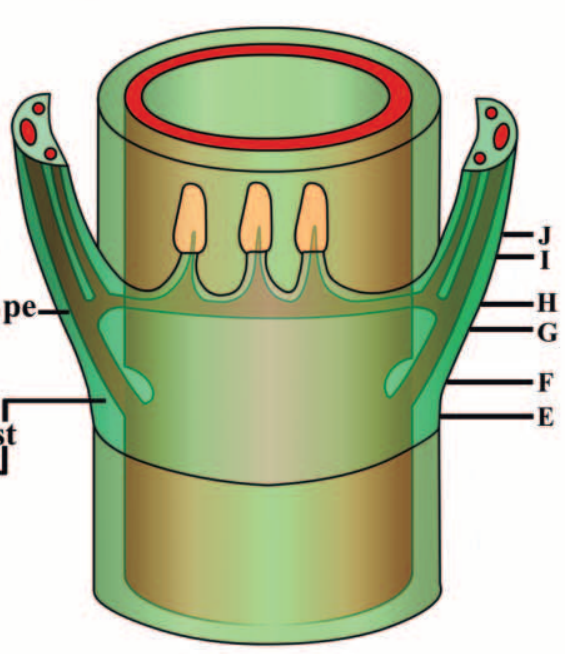

(F)
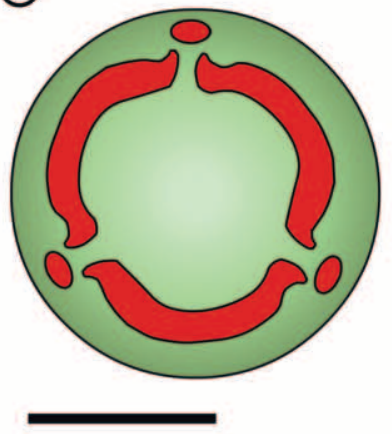

(I)

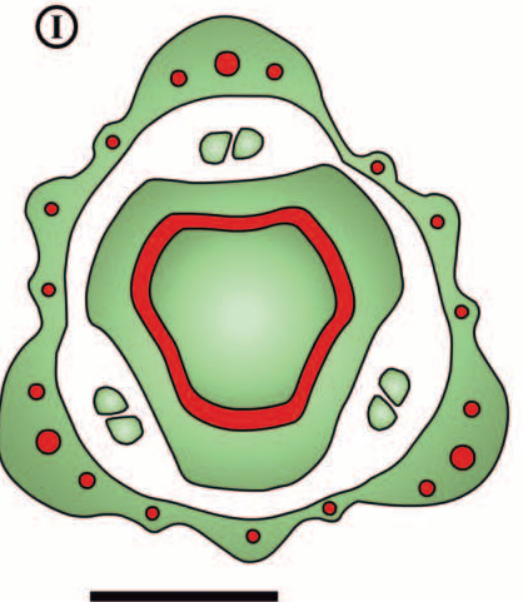

(C)
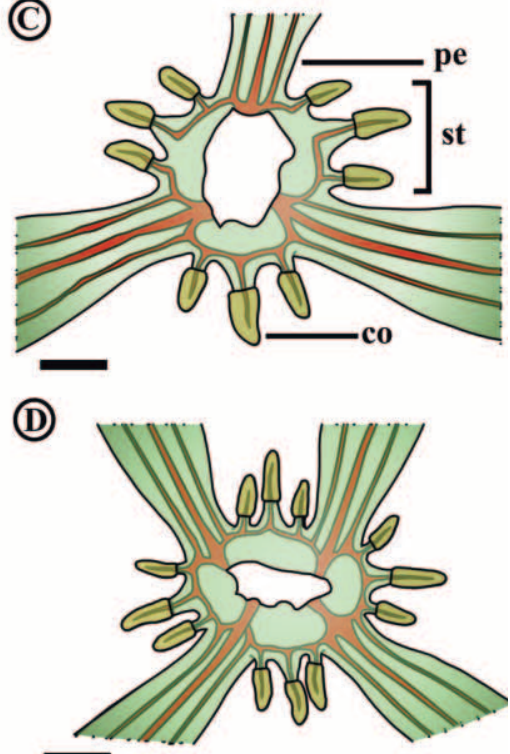

(C)

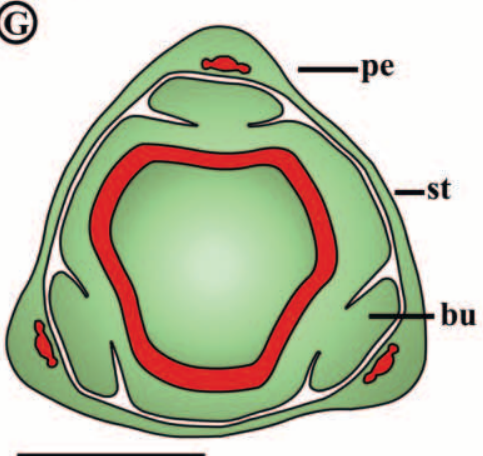

(I)

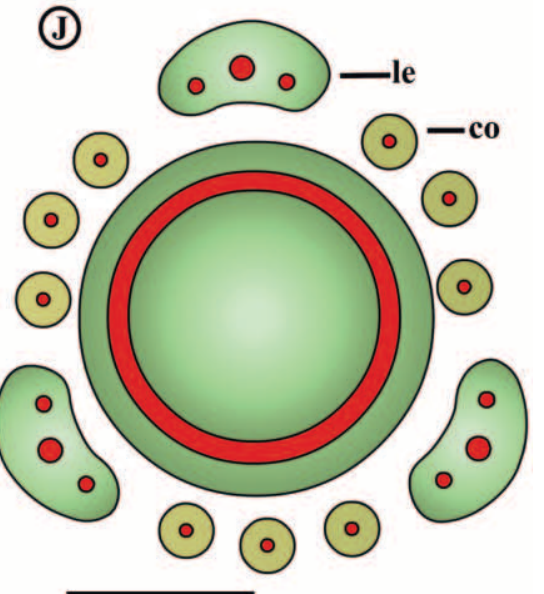

Fig. 5 Diagrams of nodal anatomy showing vascular supply to colleters of Mitracarpus polygonifolius (A) and Staelia glandulosa (B-J). $A-B$, Outline of nodal region showing stem, petioles, and interpetiolar stipules. $C-D$, Top view of node with vascular supply. $C$, Node with three leaves. D, Node with four leaves. E-J, Cross sections of a node (marked in B) showing vascularization of stem (sm), petiole (pe), stipules (st), leaves (le), and colleters (co). The position of the buds (bu) in the node is indicated only in the transverse drawings $(G-I)$. Scale bars: $0.5 \mathrm{~mm}$. 


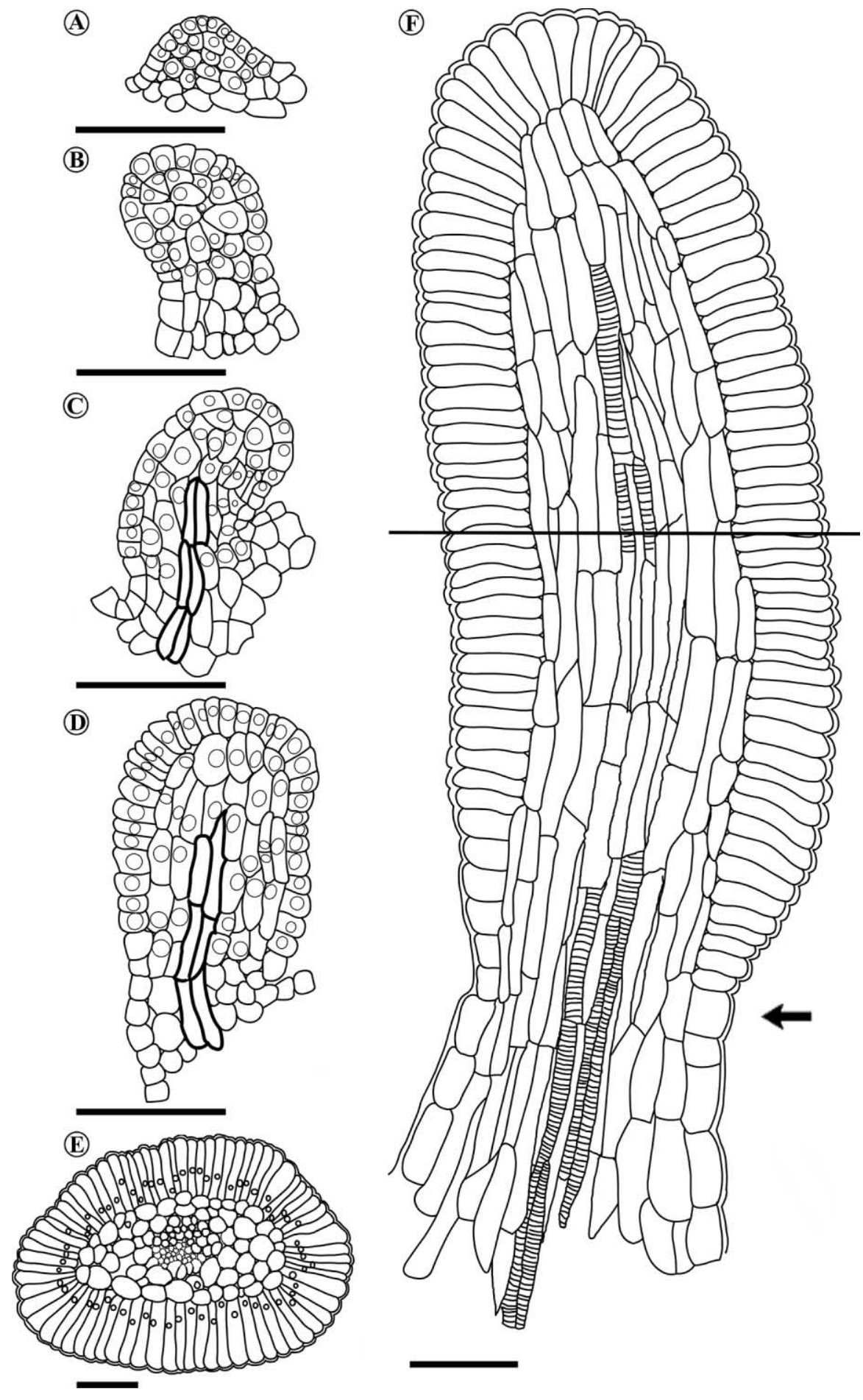

Fig. 6 Ontogeny of stipular colleters of Staelia glandulosa. A-D, Longitudinal sections of different development stages; note the procambial cells in $C$ and $D$ (darker-colored cells). E-F, Mature colleter. E, Cross section at level indicated in F. F, Longitudinal section; note the constricted base of the colleter (arrow). Scale bars: $50 \mu \mathrm{m}$.

the central core of colleters has been documented for several species of Rubiaceae (Lersten 1974a, 1974b; Dave et al. 1988; Miguel et al. 2009; Muravnik et al. 2014; Vitarelli and Santos 2009). Species with crystaliferous idioblasts in colleters also had idioblasts in other organs (Gonzalez and Tarragó 2009; Machado Martins 2012).

We found green colleters on stipules and calices in six of the analyzed species. The presence of chlorenchyma has 

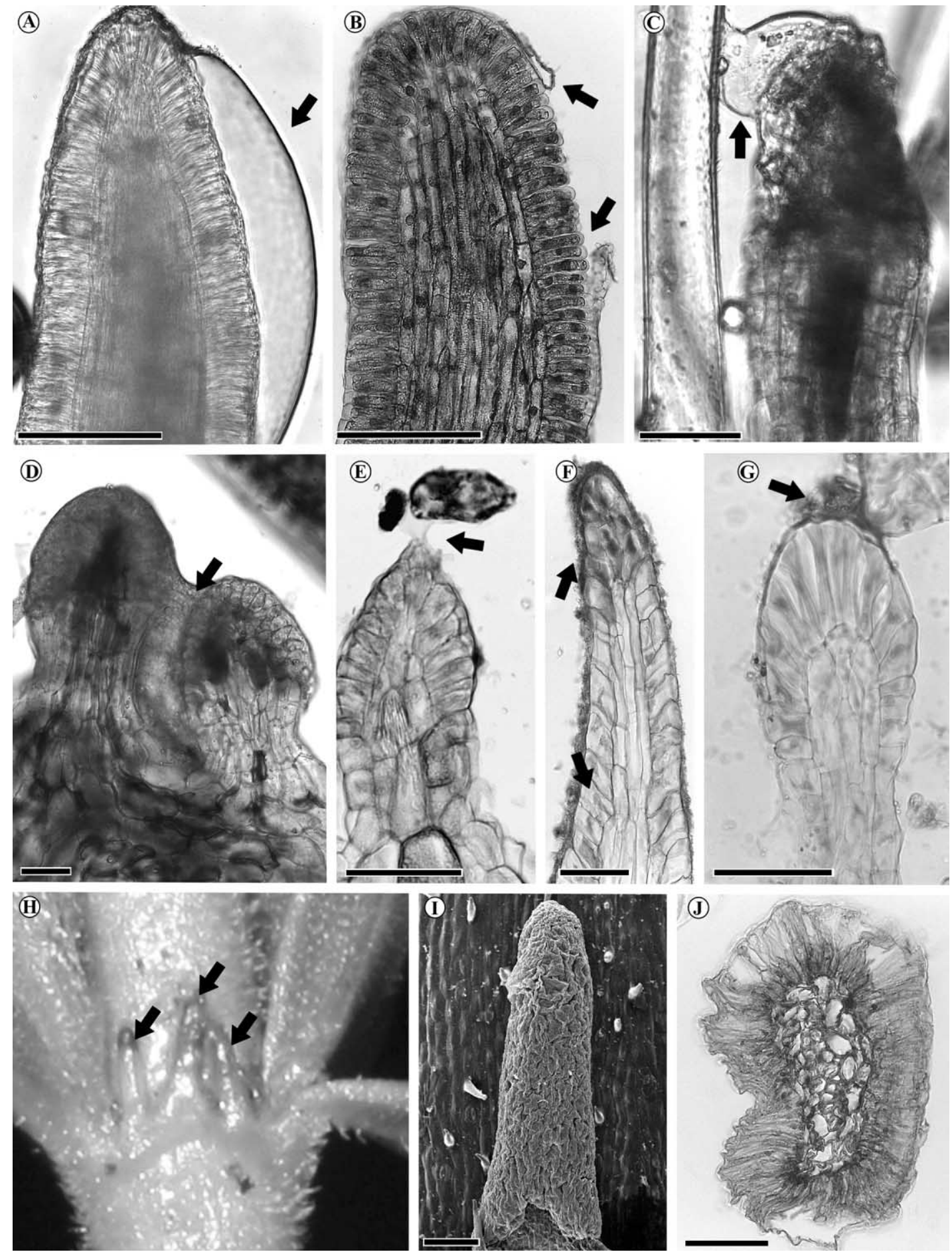

Fig. 7 Secretion and senescence of colleters, observed under LM $(A-G, J)$ and SEM $(I)$. A, Colleters in secretory phase showing cuticle displacement and accumulated secretion in the subcuticular space (arrow). $B$, Colleter with broken cuticle (arrows). C-D, Colleters in secretory phase. E-H, Old colleters with secretion residues (arrows). I-J, Senescent colleters. A-B, H-J, Staelia glandulosa. C, Richardia brasiliensis. D, Oldenlandia salzmannii. E, Galianthe hispidula. F, Manettia paraguariensis. G, Staelia virgata. Scale bars: $50 \mu \mathrm{m}$.

been mentioned in stipular colleters of a few species of Rubiaceae (Tresmondi et al. 2015), in the stalk of colleters of Allamanda L. of Apocynaceae (Ramayya and Bahadur 1968), and in the developing colleters of Macrocarpaea obtusifolia,
Gentianaceae (Dalvi et al. 2014). It has been mentioned that the presence of chlorenchyma in the latter species might be related to the production of the precursors of the secreted compounds. It is unknown whether the colleters of 
the Spermacoceae could play another role as well as the photosynthetic function. Further observations of fresh material in other genera of Spermacoceae are needed to confirm the presence of this type of tissue throughout the tribe. The presence of chlorenchyma is recorded for the first time in Borreria, D $i$ odia, Galianthe, Manettia, and Oldenlandia. Tresmondi et al. (2015) mentioned this tissue in stipules of Richardia grandiflora, and we also observed it in stipules and calyx of Richardia brasiliensis.

\section{Vascularization}

In Rubiaceae, vascularized colleters were described on stipules of several species of Bathysa C. Presl (Coelho et al. 2013) and on Simira glaziovii (K. Schum.) Steyerm. (Klein et al. 2004). Anderson (1972) indicated the presence of vascularization in the colleters of the longest fimbriae located in the interlobular position on the calyx in the genus Crusea Cham. \& Schltdl., which represented the only record for the tribe Spermacoceae. However, colleters with vascularization were also found on two species analyzed in this study: Staelia glandulosa (always in stipules, rarely in calyx) and Mitracarpus polygonifolius (only in stipules).

Two different hypotheses have been made regarding vascularization in colleters. Thomas (1991) proposed that it is always connected to the organ to which it is attached. On the other hand, Carlquist (1969) conducted a review of the evolutionary interpretations of floral structure and proposed that the vascular tissue bears a certain relationship with the size of an organ. For the colleters in Spermacoceae, the size hypothesis should be excluded. There are other analyzed species with stipular colleters that have similar sizes to those found in $S$. glandulosa $(520.37 \mu \mathrm{m})$ and M. polygonifolius $(467.37 \mu \mathrm{m})$, such as Borreria orientalis $(520.08 \mu \mathrm{m})$, Borreria palustris $(547.43 \mu \mathrm{m})$, and Diodia saponariifolia (461.66 $\mu \mathrm{m})$. However, these latter species are nonvascularized. In S. glandulosa, the Thomas proposition is the most acceptable, given the proximity of the colleter to the vascular traces of the stipule (and to the reduced lobes of calyx when present). In $M$. polygonifolius, the colleters of the internal and external fimbriae have the same proximity to the vascular traces of the stipule, but the first are nonvascularized; therefore, more studies on this species regarding the relationship between the colleters and vascularization are required.

\section{Development of Colleters}

The colleters of $S$. glandulosa are developed from both protoderm and ground elements and are, therefore, emergences, as is the case in other Rubiaceae species (Halle 1967; Dave et al. 1988; Thomas 1991; Coelho et al. 2013; Muravnik et al. 2014). Morphologically, a change in color from greenish (due to the presence of chlorophyll) to ochre-brown was observed during the development of colleters in this study. Microscopically, alteration of cell shape is observed, indicating the senescent phase of the colleters. These changes are similar to those observed by Thomas (1991) in other species. According to Esau (1965), colleters wither away after ceasing their secretory function; however, in Spermacoceae, the col- leters may be persistent structures, especially the long-lived colleters of S. glandulosa.

\section{Long-Lived Colleters and Copious Secretion}

The secretion produced by the long-lived colleters in $S$. glandulosa cover all herbaceous parts of the plant. The secretion apparently provides the plant with a defense mechanism, because ants and mites get stuck in the sticky secretion covering the stems. The exudates in $S$. glandulosa also cover older foliar nodes as well as meristems, because the colleters continue to secrete for a longer time. The cause of the longer activity of the colleters should be studied. Other cases of colleters producing an abundant secretion have been mentioned in the Rubiaceae. In Robbrechtia De Block (tribe Pavetteae, subfamily Ixoroideae), secretion from colleters (of the standard conical type) covers young shoots and parts of the inflorescences (De Block 2003). Another case is Colleteria D. W. Taylor (a rare genus without an infrafamiliar or tribal assignment), in which the copious secretion covers both apical and axillary buds (Taylor 2003). In the cases that were mentioned having profuse secretion (Robbrechtia and Colleteria), this is produced by several colleters occurring on the inner surface of stipules, whereas in S. glandulosa, there are only a few colleters located on the short fimbriae on the stipular margin. Additional field observations are necessary in $S$. glandulosa to explore the functional aspects of their colleters.

\section{Evolutionary Interpretations}

Three basic types, mainly based on the presence or absence of the vascular supply of the colleters and underlying tissues, have been defined (fig. 8): (i) type 1, colleter and underlying tissues (teeth or fimbria) without any vascular supply (teeth never seen with vascular supply); (ii) type 2 , colleter nonvascularized but fimbriae are vascularized; and (iii) type 3, colleters and fimbriae are both vascularized.

The tribe Spermacoceae is one of the few tribes in the Rubiaceae that is supported only by molecular synapomorphies (Groeninckx et al. 2009). The presence/absence of the three colleters types have been compared with one of the most comprehensive phylogenies of the tribe performed by Kårehed et al. (2008). The phylogenetic tree was adapted from Kårehed et al. (2008; fig. 8). Most of the genera studied belong to the monophyletic Spermacoce clade, which appears internally unresolved. In this tree, the presence of colleters of the three types on stipules and calyx has been mapped. Likewise, a phylogenetic tree of the Spermacoce clade recently published by Salas et al. (2015) has been used.

Type 1 colleters occur in all clades in which the species analyzed are included (Oldenlandia s.s., Manettia, Oldenlandia from South America, and the Spermacoce clade). They occur on the tip of teeth and small fimbriae. Like type 1, type 2 colleters are found in all studied genera. Type 3 colleters are much rarer. The three types of colleters may coexist in a single species or even in a single organ (e.g., stipules of M. polygonifolius). To date, type 3 , the vascularized colleter, has been recorded only in the Spermacoce clade, which appears to be an independent acquisition for the Staelia, Mitracarpus, and 


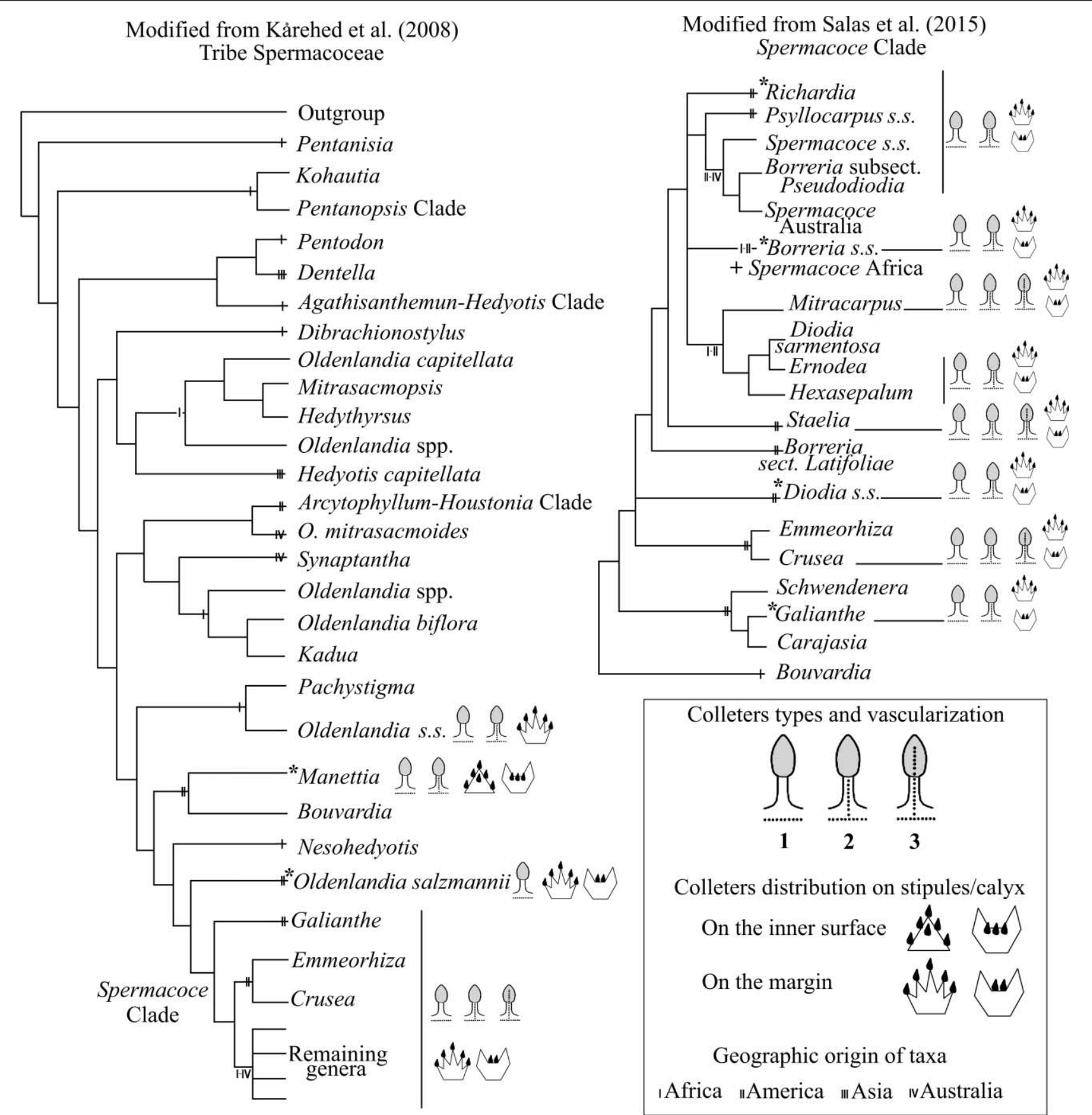

Fig. 8 Two phylogenetic trees, one representing the tribe Spermacoceae, modified from Kårehed et al. (2008; left), and the other representing the Spermacoceae clade, modified from Salas et al. $(2015$; right). Below the right tree is a schematic reproduction of the three colleters types based on patterns of vascularization. Dotted lines indicate vascular bundles. Asterisks indicate green colleters.

Crusea genera. However, more studies are needed to elucidate this aspect.

\section{Conclusion}

Our study describes the anatomy of the colleters in the tribe Spermacoceae of the Rubiaceae in detail. The presence of underground colleters in Galianthe is confirmed and extended to other species of the genus. The existence of vascularization in colleters of Mitracarpus polygonifolius and Staelia glandulosa is recorded for the first time. A new term for colleters is proposed based on anatomical, morphological, and ecological aspects: long-lived colleter. We provide data about the type, distribution, and anatomy of colleters in the Spermacoceae, contributing an important source of information for ongoing phylogenetic studies in the tribe. 


\section{Acknowledgments}

This work was funded by Proyectos de Investigación Científica y Tecnológica Orientados-Universidad Nacional del Nordeste 0199/2011 and Consejo Nacional de Investigaciones Científicas y Técnicas Proyectos de Investigación Plurianuales
112-2011-0100906 grants. We thank Elsa Cabral, Laila Miguel, Andrea A. Cabaña Fader, and Sandra Sobrado for providing fixed materials used in this work; anonymous reviewers for their valuable suggestions that improved the manuscript; and Rosemary Scoffield for reading the English manuscript critically.

\section{Appendix}

List of the analyzed species of Spermacoceae. Information about their location, habitat, and distribution is provided as follows: species; voucher information; habitat and distribution. Note: two asterisks indicate fresh material (in addition to fixed material), and the pound sign denotes herbarium specimens.

Borreria brachystemonoides Cham. \& Schltdl.; Argentina. Corrientes: Riachuelo, 27³3'42.96"S, 5844'35.31' W, 54 m, 30 Mar

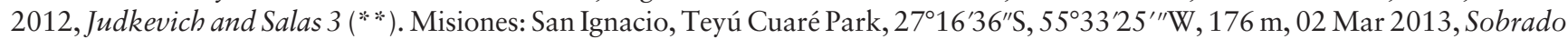
163; decumbent herbs, savannas, sometimes rocky fields; NE Argentina, South Brazil, Paraguay, and Uruguay.

Borreria orientalis E.L. Cabral, R.M. Salas \& L.M. Miguel; Argentina. Misiones: Iguazú, Iguazú National Park, 02 Mar 2013 , Sobrado $138(* *)$; decumbent herbs. Seasonally dry forest, mostly primary forest; W Paraguay, Argentina (Misiones), and Brazil (Paraná).

Borreria palustris (Cham. \& Schltdl.) Bacigalupo \& E.L. Cabral; Argentina. Misiones: San Pedro, Moconá Falls Park, 2709’11.73"S, 5353'21.21'W, 138 m, 07 Mar 2013, Judkevich 46; decumbent herbs. Atlantic humid forest, in riverine vegetation; NE Argentina, and SE and S of Brazil.

Diodia saponariifolia (Cham. \& Schltdl.) K. Schum.; Argentina. Misiones: San Pedro, Moconá Falls Park, 2709'28.3"S, 53 53'43.7"W, 536 m, 10 Dic 2011, Miguel $20\left(^{* *)}\right.$; prostrate herbs. Swampy areas, river banks; Disjunct, Mexico, SE and S Brazil, and NE Argentina.

Ernodea littoralis Sw.; Mexico. Guerrero: Acapulco, sea dunes, 20 Jan 2013, Cabral 905; much-branched decumbent shrubs. Mostly sandy soils in dunes close to the sea; Mexico and Caribbean islands.

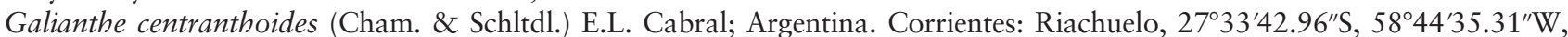
54 m, 30 Mar 2012, Judkevich and Salas 2 (\#); geoxylic shrub. Savannas with sandy soils; NE Argentina, Paraguay, SE and S Brazil, and Uruguay.

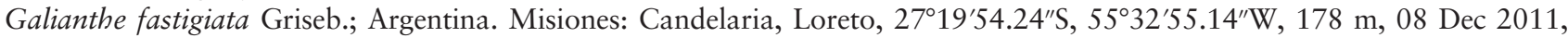

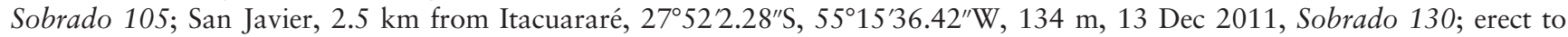
geoxylic subshrubs. Savannas, sometimes rocky fields; NE Argentina, South Brazil, Paraguay, and Uruguay.

Galianthe grandifolia E.L. Cabral; Brazil. Distrito Federal: Planaltina, Apr 2009, Queiróz et al. 14015; geoxylic shrub. Savannas with lateritic and sandy soils; Central, SE, NE, and N Brazil.

Galianthe hispidula (A. Rich. ex DC.) E.L. Cabral \& Bacigalupo; Argentina. Misiones: Manuel Belgrano, Urugua-í Park, $25^{\circ}$ 51'27.8"S, 54¹0'06.1”W, 240 m, 03 Apr 2013, Miguel 62 (**); rhizomatous herbs, Atlantic humid forest, in riverine vegetation; NE Argentina, Paraguay, and SE and S of Brazil.

Galianthe valerianoides (Cham. \& Schltdl.) E.L. Cabral.; Argentina. Misiones: Manuel Belgrano, 26¹6'29.04"S, 5341'59.52"W, 815 m, 10 Dec 2011, Miguel 16 (\#); rhizomatous subshrubs. Lowland savanas; NE Argentina, Paraguay, and S Brazil.

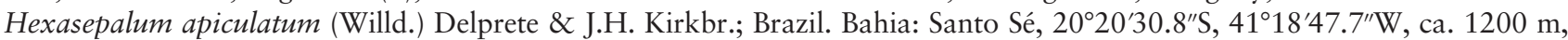
28 May 2010, Salas 457; shrub or herbs, decumbent or erect. Savannas, rocky fields, edge of deciduous forest; America, from Mexico to Paraguay, including Caribbean region. Introduced in tropical Africa.

Manettia cordifolia Mart.; Argentina. Misiones: Iguazú, Iguazú National Park, 02 Mar 2013, Sobrado 147; climbing subshrubs. Edge of dry or humid forest, occasionally bush savannas; South America.

Manettia paraguariensis Chodat.; Argentina. Misiones: Iguazú, Iguazú National Park, 02 Mar 2013, Sobrado 141; San Pedro, Cruce Caballero Park, 26³1'08.1"S, 5359'20.2”W, 626 m, 05 Mar 2013, Judkevich 31 (**); climbing subshrubs. Edge of humid forest; NE Argentina, Paraguay, and S Brazil.

Mitracarpus megapotamicus (Spreng.) Kuntze.; Argentina. Formosa, Guaycolec, 11 Set 2014, Judkevich and Salas 60; decumbent subshrub. In savannas or disturbed areas, mainly in sandy soils; N Argentina, S Bolivia, Paraguay, S Brazil, and NE Uruguay.

Mitracarpus pusillus Steyerm.; Brazil. Minas Gerais: Joaquím Felício, 17²4'57"S, 44¹6'29”W, 1140 m, 17 Apr 2012 , Viana 5888; erect herbs. In deep and sandy soils of Espinhaço Mountains Range; Minas Gerais, Brazil.

Mitracarpus polygonifolius (A. St.-Hil.) R.M Salas \& E.B. Souza; Brazil. Minas Gerais: Santana do Riacho, 19¹5'53.1"S, 4331'22.5”W, 1325 m, 15 Apr 2012, Viana 5906; erect shrub. Open, bush or rocky savannas; widespread in NE Brazil and French Guiana.

Oldenlandia corymbosa L.; Brazil. Minas Gerais: Januaria, 15²9'30"S, 44²1'35"W, 548 m, 18 Apr 2012, Viana 5896; herbs. Large ecological amplitude, disturbed areas; widespread in tropics of America, Africa and Asia.

Oldenlandia salzmannii (DC.) Benth. \& Hook. f. ex B.D. Jacks; Argentina. Corrientes: San Cosme, RN 12, 1075 km, 15 Jun 2015, Salas 498 (*); prostrate herbs. Lowland savannas; South America, introduced in USA.

Planaltina capitata (K. Schum.) R. M. Salas \& E. L. Cabral; Brazil. Goiás: Colinas do Sul, 14¹2’07.2”S, 4751'22.9”W, 913 m, 25 Apr 2009, Cardoso 2573; erect shrub. Bush savannas; Central Brazil. 


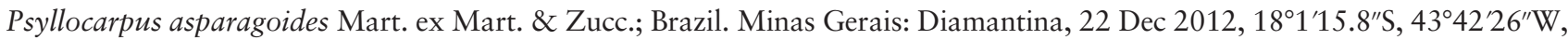
1255 m, Sobrado 153; erect shrub. Rocky fields; Bahia and Minas Gerais, Brazil.

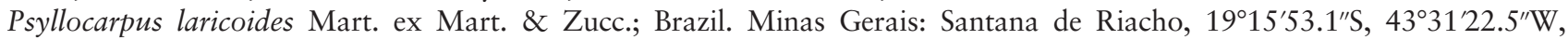
1325 m, 15 Apr 2012, Sobrado 136; erect shrub. Rocky fields; Bahia and Minas Gerais, Brazil.

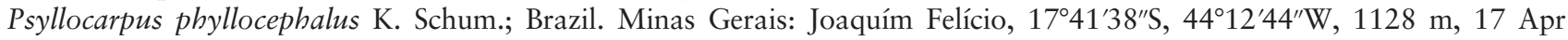
2012, Viana 5885; erect shrub. Rocky fields; Goiás and Minas Gerais, Brazil.

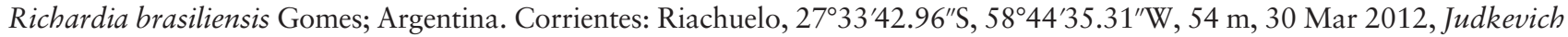
and Salas $4(* *)$; herbs. Large ecological amplitude, disturbed areas; widespread in tropics of the Americas.

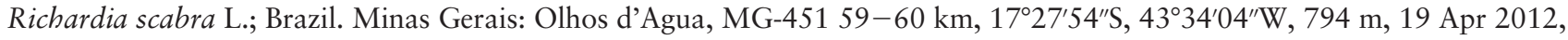
Viana 5912; herbs. Large ecological amplitude, disturbed areas; widespread in tropics of the Americas.

Spermacoce prostrata Aubl.; Argentina. Misiones: San Javier, $2.5 \mathrm{~km}$ de Itacuararé, 27 $52^{\prime 2} 2.28^{\prime \prime} \mathrm{S}, 55^{\circ} 15^{\prime} 36.42^{\prime \prime} \mathrm{W}, 134 \mathrm{~m}$, 13 Dic 2011, Sobrado 129; herbs. Large ecological amplitude, including humid and dry forest, riverine vegetation, rocky fields; widespread, tropical areas of America, Asia, and Oceania.

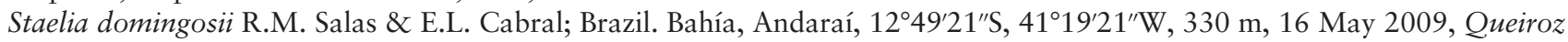
14599; subshrub. Deep sandy dunes. Caatinga; Bahia, Brazil.

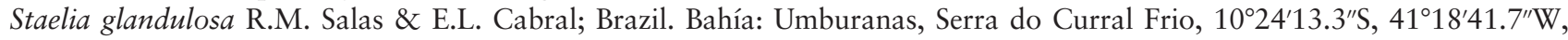
905 m, 28 May 2010, Queiroz 14813; Salas 451; Cardoso 2989; shrub. Deep sandy dunes. Caatinga; Bahia, Brazil.

Staelia virgata (Link. ex Roem. \& Schutl.) K. Schum.; Argentina. Salta: Coronel Juan Solá, 2328 $40^{\prime \prime}$ S, 62 ${ }^{\circ} 53^{\prime} 52.06^{\prime \prime} \mathrm{W}$, 223 m, 9 Jan 2010, Salas 469; subshrub. Large ecological amplitude deep. Mostly sandy dunes; N Argentina, Bolivia, Brazil, and Paraguay.

\section{Literature Cited}

Anderson WR 1972 A monograph of the genus Crusea (Rubiaceae). Mem N Y Bot Gard 22:1-128.

Appezzato-da-Gloria B, MEM Estelita 2000 Development, structure and distribution of colleters in Mandevilla illustris and M. velutina (Apocynaceae). Rev Bras Bot 23:113-120.

Bacigalupo NM 1996 Flora del Valle de Lerma. Rubiaceae Juss. Aportes Botánicos de Salta. Ser Flora 4:52.

Bacigalupo NM, EL Cabral 2007 Rubiaceae, Tribu Spermacoceae. Flora Fanerogâmica do Estado de São Paulo. Pages 276-441 in M Wanderley, G Shepherd, T Melhem, AM Giulietti, eds. Instituto de Botânica, Sao Paulo, Brazil.

Barreiro DP, SR Machado 2007 Coléteres dendróides em Alibertia sessilis (Vell.) K. Schum., uma espécie não-nodulada de Rubiaceae. Rev Bras Bot 30:387-399.

Borhidi A 2006 Rubiáceas de México. Akadémiai Kiadó, Budapest, Hungary.

Carlquist T 1969 Toward acceptable evolutionary interpretations of floral anatomy. Phytomorphology 19:332-362.

Coelho VPM, JPV Leite, LG Fietto, MC Ventrella 2013 Colleters in Bathys a cuspidata (Rubiaceae): development, ultrastructure and chemical composition of the secretion. Flora 208:579-590.

Dalvi VC, LS Cardinelli, RMSA Meira, AA Azevedo 2014 Foliar colleters in Macrocarpaea obtusifolia (Gentianaceae): anatomy, ontogeny, and secretion. Botany 92:59-67.

Dave Y, PM Kuriachen, V Thomas 1988 Development, structure and senescence of colleters in Gardenia lucida Roxb. (Rubiaceae). Acta Soc Bot Pol 57:3-7.

De Block P 2003 Robbrechtia, a new Rubiaceae genus from Madagascar. Syst Bot 28:145-156.

Delprete PG 2010 Rubiaceae. Gêneros A-H. Pages 376-1012 in JÂ Rizzo, ed. Flora dos Estados de Goiás e Tocantins-Coleção Rizzo. Universidade Federal de Goiás and Institut de Recherche pour le Développement, Goiânia, Brazil.

Esau K 1965 Plant anatomy. Wiley, New York.

Goevarts R, M Ruhsam, L Andersson, E Robbrecht, D Bridson, A Davis, I Schanzer, B Sonke 2011 World checklist of Rubiaceae. Royal Botanic Gardens, Kew. http://www.kew.org/wcsp/rubiaceae/. Gonzalez AM, CL Cristóbal 1997 Anatomía y ontogenia de semillas de Helicteres lhotzkyana (Sterculiaceae). Bonplandia 9:287-294.
Gonzalez AM, CR Salgado, A Fernández, MM Arbo 2012 Anatomy, pollen, and chromosomes of Adenoa (Turneraceae), a monotypic genus endemic to Cuba. Brittonia 64:208-225.

Gonzalez AM, DJ Tarragó 2009 Anatomical structure and secretion compounds of colleters in nine Ilex species (Aquifoliaceae) from southern South America. Bot J Linn Soc 160:197-210.

Groeninckx I, S Dessein, H Ochoterena, C Persson, TJ Motley, J Kårehed, B Bremer, S Huysmans, WE Smets 2009 Phylogeny of the herbaceous tribe Spermacoceae (Rubiaceae) based on plastid DNA data. Ann Mo Bot Gard 96:109-132.

Gustafsson CGR 1998 The neotropical Rosenbergiodendron (Rubiaceae, Gardenieae). Brittonia 50:452-466.

Hallé F 1967 Étude biologique et morphologique de la Tribu des Gardeniées (Rubiacées). Mem ORSTOM 22:1-146.

Johansen DA 1940 Plant microtechnique. McGraw-Hill, San Francisco.

Judkevich MD, RM Salas, AM Gonzalez 2015 Revisión de Randia (Rubiaceae) en Argentina, taxonomía y morfoanatomía. Bol Soc Argent Bot 50:607-625.

Kårehed J, I Groeninckx, S Dessein, TJ Motley, B Bremer 2008 The phylogenetic utility of chloroplast and nuclear DNA markers and the phylogeny of the Rubiaceae tribe Spermacoceae. Mol Phylogenet Evol 49:843-866.

Kirkbride JH Jr 1979 Revision of the genus Psyllocarpus (Rubiaceae). Smithson Contrib Bot 41:1-32.

Klein DE, VM Gomes, SJ Da Silva-Neto, M Da Cunha 2004 The structure of colleters in several species of Simira (Rubiaceae). Ann Bot 94:733-740.

Lersten NR 1974a Colleter morphology in Pavetta, Neorosea and Tricalysia (Rubiaceae) and its relationship to the bacterial leaf nodule symbiosis. Bot J Linn Soc 69:125-136.

$1974 b$ Morphology and distribution of colleters and crystals in relation to the taxonomy and bacterial leaf nodule symbiosis of Psychotria (Rubiaceae). Am J Bot 61:125-136.

1975 Colleter types in Rubiaceae, especially in relation to the bacterial leaf nodule symbiosis. Bot J Linn Soc 71:311-319.

Low YW, KM Wong 2007 Two new species of Gardenia (Rubiaceae) from Borneo and notes on Gardenia pterocalyx. Edinb J Bot 64:2536. 
Luque R, HC Sousa, DJE Kraus 1996 Métodos de coloração de Roeser (1972)-modificado-e Kropp (1972) visando a substituição do azul de astra por azul de alcião 8 GS ou 8 GX. Acta Bot Bras 10:199-212.

Machado SR, LPC Morellato, MG Sajo, PS Oliveira 2007 Morphological patterns of extrafloral nectaries in woody plant species of the Brazilian cerrado. Plant Biol 10:660-673.

Machado Martins F 2012 Leaf and calycine colleters in Odontadenia lutea (Apocynaceae-Apocynoideae-Odontadenieae): their structure and histochemistry. Braz J Bot 35:59-69.

Mayer JLS, P Cardoso-Gustavson, B Appezzato-Da-Glória 2011 Colleters in monocots: new record for Orchidaceae. Flora 206: 185-190.

Mayer JLS, SM Carmello-Guerreiro, P Mazzafera 2013 A functional role for the colleters of coffee flowers. Ann Bot Plants 5:1-13.

Miguel EC, D Gomes De Moraes, M Da Cunha 2009 Stipular colleters in Psychotria nuda (Cham. \& Schltdl.) Wawra (Rubiaceae): micromorphology, anatomy and cristals microanalysis. Acta Bot Bras 23:1034-1039.

Miguel EC, V Moreira Gomes, MA De Oliveira, M Da Cunha 2006 Colleters in Bathysa nicholsonii K. Schum. (Rubiaceae): ultrastructure, secretion protein composition, and antifungal activity. Plant Biol 8:715-722.

Muravnik LE, OV Kostina, AL Shavarda 2014 Development, structure and secretion compounds of stipule colleters in Pentas lanceolata (Rubiaceae). S Afr J Bot 93:27-36.

Ramayya N, B Bahadur 1968 Morphology of the "squamellae" in the light of their ontogeny. Curr Sci (Bangalore) 37:520-522.

Robbrecht E 1988 Tropical woody Rubiaceae. Opera Bot Belg 1:1271.
Rutishauser R 1983 Leaf whorls and stipules in the Rubieae (Rubiaceae). Acta Bot Neerl 32:360-361.

Salas RM, EL Cabral 2010 Planaltina nuevo género de la Tribu Spermacoceae (Rubiaceae), endémico del Planalto Central de Brasil y una nueva especie del Estado de Goiás, Brasil. J Bot Res Inst Tex 4:193-206.

Salas RM, EL Cabral, PL Viana, S Dessein, S Jansen 2015 Carajasia (Rubiaceae), a new and endangered genus from the Carajás mountain range, Pará, Brazil. Phytotaxa 206:14-29.

Solereder H 1908 Systematic anatomy of the Dicotyledons. Clarendon, Oxford.

Taylor DW 2003 Colleteria (Rubiaceae), a new genus from the Caribbean. Syst Geogr Plants 73:199-208.

Thomas V 1991 Structural, functional and phylogenetic aspects of the colleter. Ann Bot 68:287-305.

Thomas V, Y Dave 1989 Structure, origin, development and senescence of colleters in Nerium indicum Mill. (N. odorum Soland., Apocynaceae). Korean J Bot 32:163-172.

Tresmondi F, A Nogueira, E Guimarães, SR Machado 2015 Morphology, secretion composition, and ecological aspects of stipular colleters in Rubiaceae species from tropical forest and savana. Sci Nat 102:73.

Vilhalva DAA 2008 Estudo morfofisiologico do desenvolvimento das especies Galianthe grandifolia E. L. Cabral (Rubiaceae) e Campulocliniun chlorolepis Baker (Asteraceae) submetidas a diferentes concentrações de cadmio (tesis doctoral). Universidade Estadual de Campinas, Sao Paulo, Brazil.

Vitarelli NC, M Santos 2009 Anatomia de estípulas e coléteres de Psychotria carthagenensis Jacq. (Rubiaceae). Acta Bot Bras 23:923928. 